\title{
SYSTEMIC DELIVERY OF SMALL INTERFERING RNA THERAPEUTICS: OBSTACLES AND ADVANCES
}

\author{
Akash Chandela ${ }^{1}$ and Yoshihito Ueno ${ }^{1,2^{*}}$ \\ ${ }^{1}$ United Graduate School of Agricultural Science, Gifu University, 1-1 Yanagido, Gifu City 501-1193, Japan \\ ${ }^{2}$ Course of Applied Life Science, Faculty of Applied Biological Sciences, Gifu University, 1-1 Yanagido, Gifu City 501-1193, Japan
}

\begin{abstract}
RNA interference (RNAi) has emerged as a critical tool for genetic therapeutics. Within the last two decades, there have been extensive investigations in the systemic delivery of these drugs but the obstacles in in vivo delivery have possessed a great difficulty in their administration. These developments led to the advances in systemic administration with designing and incorporation of various drug carriers, including bioconjugate systems, polymeric complexes, organic and inorganic nanoparticles. However, successful translation of these drug delivery systems for the clinical application has still been a great setback for these class of pharmaceutics. In order to improve their competency and applicability, systemic evaluation of currently available carrier systems is required. In this review, we focus on the obstacles in the systemic administration of small interfering RNAs (siRNAs) and the advances with various carrier systems to overcome the limitations of these obstacles. General obstacles in siRNA delivery have been discussed with major emphasis on the barriers at different stages of systemic administration. Then, advances in their application for targeted delivery with rationally designed carrier systems such as bioconjugates, polymeric complexes, and nanoparticles have been introduced. Lastly, we discuss the progress and state of clinical studies of siRNA therapeutics with perspectives of clinical potential. Keywords: Bioconjugate, Clinical study, Nanoparticles, RNAi, siRNA, Systemic administration
\end{abstract}

\section{Introduction}

RNA interference (RNAi) is a conserved self-defense mechanism found in most eukaryotes, which was initially discovered in Caenorhabditis elegans (Fire et al., 1998). In this phenomenon, small double-stranded RNA (dsRNA) triggers a series of biochemical events and results in sequence-specific gene suppression (Fire, 1999; Hammond et al., 2001; Sharp, 2001; Tuschl, 2001). The capability of this tool to potentially silence any gene, including the intracellular (undruggable) targets, has inspired the scientific community to understand and exploit it for efficient application as a new class of pharmaceutics (Wu et al., 2014; Finan et al., 2017; Tushir-Singh, 2017). Particularly, RNA duplexes 2123 nucleotides in length, also known as small interfering RNAs (siRNAs), have emerged as the leading candidates with the evidence of RNAi in mammalian cells (Elbashir et al., 2001a). However, the translation of siRNA drugs to the clinical application has remained slow, with a number of challenges posing a barrier for the efficient intracellular delivery of these therapeutics.

The very first clinical trial involving siRNA was conducted in 2004 with patients suffering from age-related macular degeneration (AMD) (Garba and Mousa, 2010). In 2006, Andrew Z. Fire and Craig C. Mello were awarded the Nobel Prize in Physiology or Medicine for discovering RNAi. And now, in 2018, the latest development has been the approval of the first siRNA drug ONPATTRO, for the treatment of the polyneuropathy of hereditary transthyretin-mediated (TTR) amyloidosis in adults (Adams et al., 2018). It has taken nearly two decades and ample efforts for the approval of the first drug, which can be attributed to the problems associated with siRNA such as hydrolysis by nucleases, large size, and hydrophilic nature (Sarett et al., 2015). Chemical modifications of siRNAs have provided them considerable stability in most of the cases, whereas shielding the siRNA with carriers have further regulated the targeted systemic delivery (Shukla et al., 2010; Xu et al., 2015; Ku et al., 2016; Lee et al., 2016). Between the local 
and systemic administration, the former has advantages of reduced off-target side effects and enables higher gene silencing but failed in initial clinical trials, disappointing the scientific community (Haussecker, 2014; Xue et al., 2014).

Design and development of advanced delivery systems have notably increased the siRNA therapeutics in clinical trials and most of these are targeted via systemic delivery (Ozcan et al., 2015; Chakraborty et al., 2017). Many groups have reported systemic delivery of siRNA with different carrier systems such as bioconjugates (Ming and Laing, 2015; Lee et al., 2016; Sivakumar et al., 2018; Srimanee et al., 2018), complexes (Biswas and Torchilin,
2013; Nussbaumer et al., 2016; Takemoto and Nishiyama, 2017) and nanoparticles (Patil and Panyam, 2009; Kozielski et al., 2013; Lin et al., 2014; Tezgel et al., 2018). Recent developments have been the combinatorial formulation of carriers to form complexes on the nanoscale for the systemic delivery of siRNA therapeutics (Garg et al., 2016; Lee and Ahn, 2018; Zheng et al., 2018).

Since RNA therapeutics are still at an early stage, many researchers have been actively working in this domain but only a few studies provide such comparative study of carrier systems and their developments at different phases. Therefore, in this review, we present recent remarkable contributions to systemic

\section{A. antisense 3'- 5'- (guide)

B.

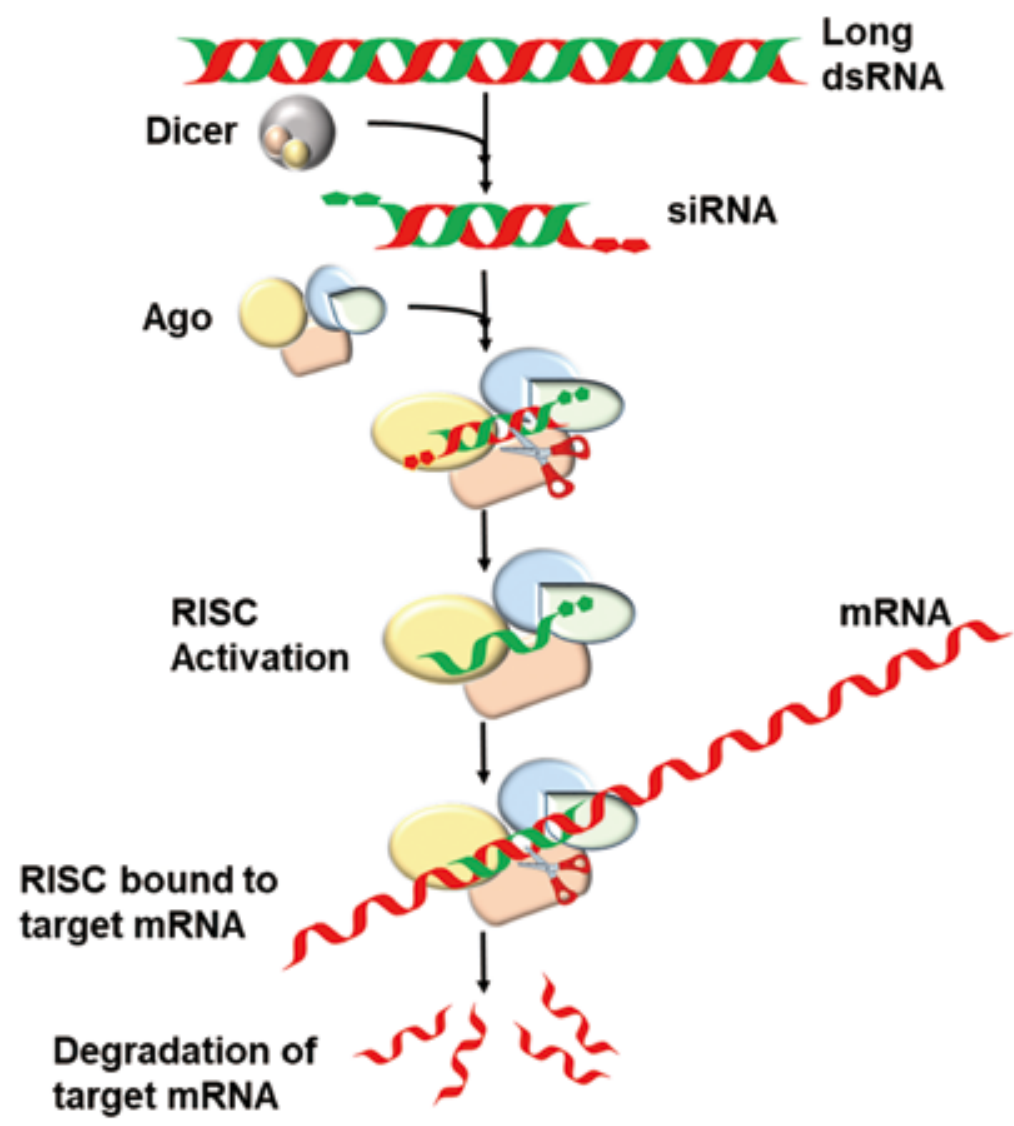

Fig.1 A. The structure of siRNA, sense and antisense strands, and target mRNA complementary seed region. B. Schematic of siRNA-mediated gene silencing. 
delivery of siRNA to fight various barriers. First, extracellular and intracellular obstacles in the systemic administration of siRNA are described. Second, we introduced advances with each carrier system by utilizing their respective mode of action, their pros, and cons for effective siRNA delivery. Lastly, the current state of siRNA therapeutics in clinical studies and application have been discussed.

\section{2. siRNA-Mediated Gene Silencing Mechanism}

siRNAs are short, double-stranded regulatory RNAs that contain two signature characteristics: a two nucleotide 3'-end overhang and a phosphorylated 5'-end (Elbashir et al., 2001a, 2001b). Cutting long dsRNAs using the dicer endoribonuclease leads to the formation of these siRNAs. The functional strand, complementary to the target mRNA, is called the guide strand, whereas the non-functional strand is called passenger strand (Fig. 1A). The Argonaute (AGO) protein recognizes and guides the siRNA for target mRNA degradation by detecting the seed region complementary to the target mRNA (Frank et al., 2010; Schirle and MacRae, 2012). The siRNA-mediated gene silencing follows recognition by Ago2, sense strand cleavage, RNAinduced silencing complex (RISC) activation, and target mRNA degradation in a sequential manner (Fig. 1B).

\section{Delivery of siRNA Therapeutics and Obstacles 3.1. Local and systemic delivery}

The delivery method of siRNA can be broadly classified on the basis of route of administration i.e. local administration and systemic administration. The local delivery is targeted for topical and oral application for the treatment of diseases related to eye, skin, vagina and nasal, where the target sites are easily accessible (Martirosyan et al., 2014; Pan et al., 2015). Whereas, the systemic administration is required for the treatment of metastatic or deepseated tumors like the liver diseases (Gujrati and Lu, 2013; Hattori et al., 2015; Zuckerman and Davis, 2015). The inhibition of respiratory viruses by nasally administered locoregional delivery of siRNA demonstrates efficient drug activity upon regional delivery (Bitko and Barik, 2008). Systemic delivery of siRNA to the liver and lung helps in eradicating metastatic tumors (Yang et al., 2012; Huang et al., 2015). Therefore, systemic administration is a preferred method for siRNA delivery over the local delivery. Also, since most of the cancers are metastatic in nature, their treatment requires systemic siRNA delivery to the target tissue for highly efficient activity.

\subsection{General obstacles in siRNA delivery}

Translation of siRNA therapeutics to clinical application is strenuous and still remain an enormous challenge. While ample efforts have been applied for the development of these synthetic drugs but the major limitation is their delivery to the site of action as they face a number of extracellular as well as intracellular barriers, as shown in Fig. 2 (Borna et al., 2015; Roberts et al., 2016). The extracellular barriers comprise of the degradation by nucleases, renal clearance, and uptake by the reticuloendothelial systems. Many chemical modifications have evidently enhanced the stability of siRNAs and protected against hydrolysis by the nucleases (Ueno et al., 2008, 2009; Chernikov et al., 2017; Gvozdeva et al., 2018). Small size and molecular weight lower than $40 \mathrm{kDa}$ render the siRNA prone to the kidney filtration process. Therefore, carrier systems with a hydrodynamic size of over $6 \mathrm{~nm}$ and increased the molecular weight are required (Zuckerman et al., 2012; Bienk et al., 2016). Immunostimulation is another barrier in the delivery of siRNA as it leads to degradation of siRNA after recognition as an alien moiety by the macrophages and kupffer cells (Whitehead et al., 2011; Khairuddin et al., 2012). In order to tackle this issue, 2'-position of the ribose sugar had been modified with 2'-O-methyl and 2'-fluoro groups to suppress the immune response and improve serum provide stability (Valenzuela et al., 2014; Haraszti et al., 2018).

Intracellular barriers inhibit the siRNA to permeate the lipid bilayers due to charge repulsion. Hence, cationic delivery systems are utilized for the transport of siRNA inside the cell via endocytosis. The endosomal $\mathrm{pH}$ is lower than that of the cytosol and the release can be mediated through a proton pump, inability to do so leads to degradation by the lysosome limiting the bioavailability of siRNA to interact with RISC machinery in the cytosol (Ma, 2014; Tuttolomondo et al., 2017).

\section{Obstacles in the Systemic Administration of siRNA}

Systemic siRNA delivery is more advanced and complicated in comparison to the local administration. In the last decade, 50\% percent of the clinical trials have been executed with systemic delivery as they efficiently distribute siRNA to metastatic cancer. Obstacles in systemic delivery viz. the nuclease degradation in the blood vessels, uptake by reticuloendothelial cells, biodistribution to the target site, extravasation from blood vessels to target tissues, and permeation to the target site (Fig. 3). Lastly, endocytosis by the cell and endosomal escape constitute the complete list of obstacles in the systemic administration. Although the requirement of a carrier system for different routes of delivery has a considerable overlap, it is necessary for a carrier system to deliver the drug systematically rather than topically or locally.

\subsection{Blood Circulation: Degradation by Nucleases and Renal Filtration}

Systemic delivery is initiated with intravenous injections siRNA to traverse through blood vessels and reach the target tissue/organ. But the blood plasma contains several nucleases 

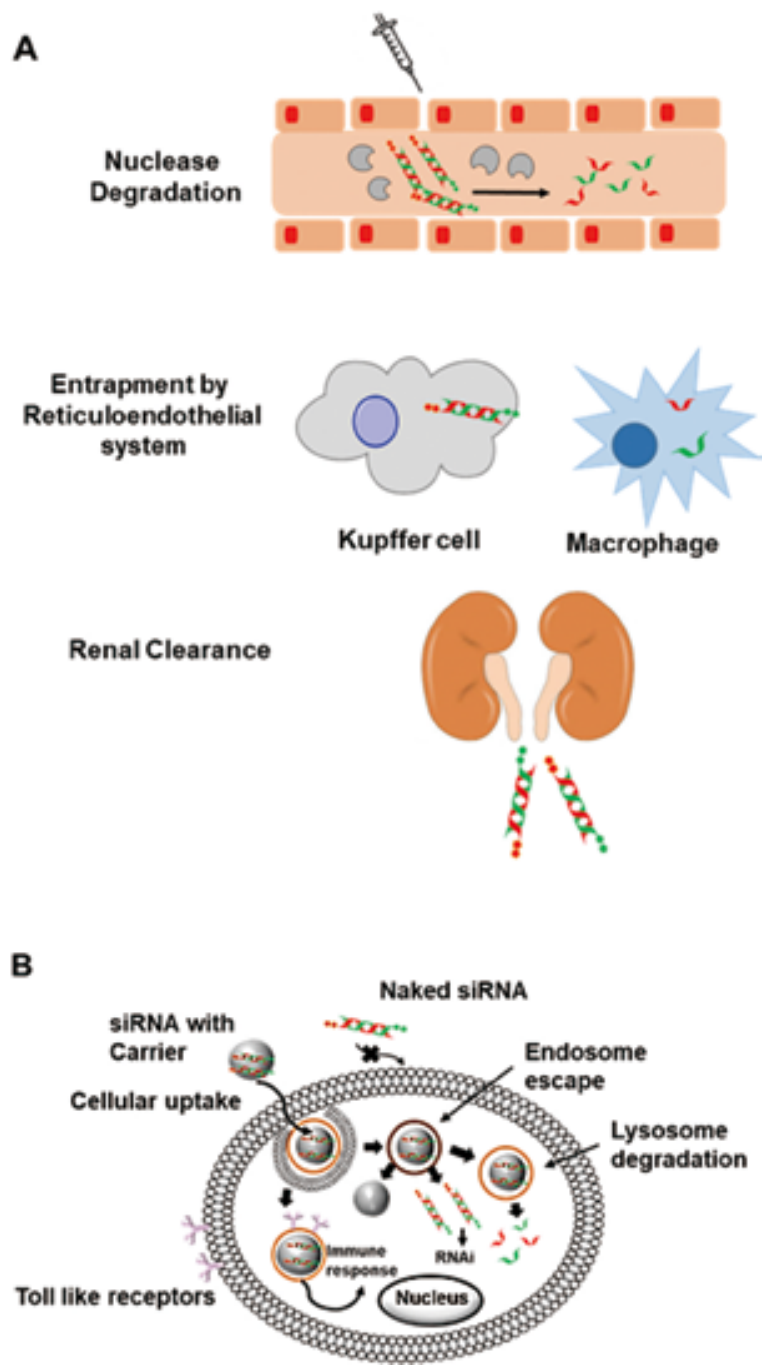

Fig.2 General obstacles in the delivery of siRNA-based therapeutics, (A) extracellular and (B) intracellular.

which hydrolytically degrade the siRNA. Chemical modifications and substitution of phosphate backbone with phosphorothioate linkage yields serum stable siRNAs (Ueno et al., 2008; Sierant et al., 2013; Chernikov et al., 2017; Ogata et al., 2017). Thereby, chemical modifications have become vital tools in enhancing the nuclease resistance of siRNAs. Also, bioconjugates such as cholesterol have provided longer half-life due to sustained stability against serum as these lipoproteins are transported in the bloodstreams (Ding et al., 2012; Khan et al., 2016).

Rapid renal clearance is subjected for small molecules with molecular weights of less than $40 \mathrm{kDa}$ to pass through glomerular of the kidney. Hence, siRNAs are liable enough to flush out of the system through kidney filtration unit, resulting in loss-of-function of gene regulation. Therefore, conjugation or encapsulation siRNAs to carrier systems help in improving its size and mass to avoid renal filtration (Zuckerman et al., 2012).

\subsection{Biodistribution: Off-target Delivery and Accumulation in the}

Reticuloendothelial System

During the systemic delivery of siRNA, many off-target sites are recognized due to seed region complementarity and accumulation takes place (Gresham, 2003; Lin et al., 2005). Some structurally modified siRNAs and conjugated systems have shown on-target delivery (Suter et al., 2016; Janas et al., 2018). Therefore, siRNA modification and a suitable delivery agent can help in reducing off-target activity. Secondly, the 


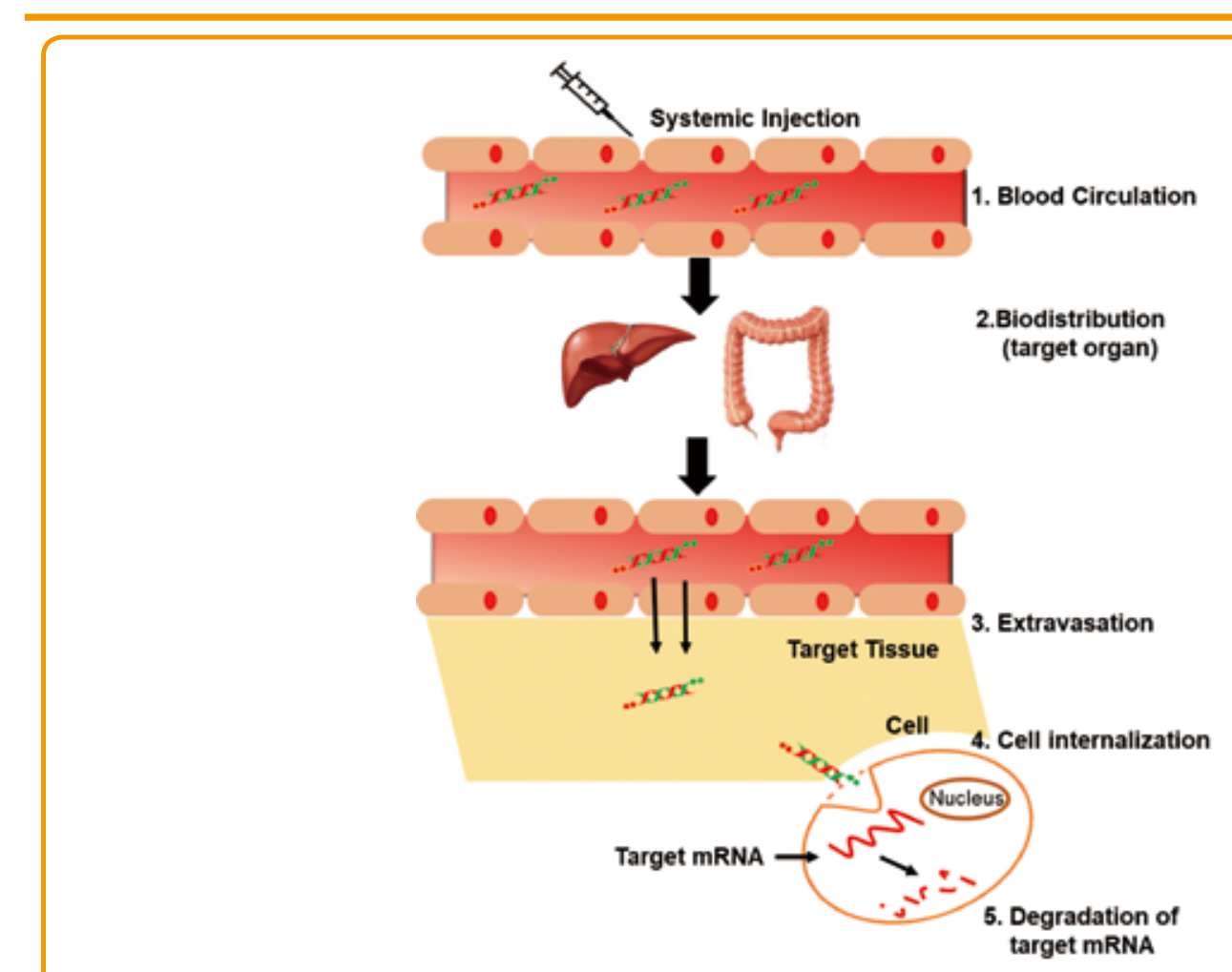

Fig.3 Schematic of Systemic administration of siRNA with various barriers at each stage.

reticuloendothelial system (RES), also known as the macrophage system, an immune system in the blood, connective tissues, liver, spleen, lungs, and bone marrow, activates and captures the siRNA as an immune response (Whitehead et al., 2009; Wang et al., 2010). Nanoparticles, which are relatively smaller than polymers, have been shown to escape RES uptake (Huang and Guo, 2011). Circulation time and on-target delivery have been reported to increase upon siRNA conjugation with polyethylene glycol (Bao et al., 2013; Miteva et al., 2015).

\subsection{Cellular Uptake: Extravasation and Cell Internalization}

Localization of siRNAs at the target organ happens by transcytosis, hence it is important to have a small particle size for easy movement between the cells and reach the target site. Cell internalization is limited due to the anionic nature of the membrane surface causing repulsion of likely charged siRNA (Whitehead et al., 2009). Cellular uptake of siRNA is usually done via endocytosis, where membrane-bound endosomes trap the siRNA and later release it into the cytosol. Naked siRNA cannot permeate cell membrane, hence cationic molecules or nanoplexes are used to mediate the delivery through the cell membrane. The anionic proteoglycans on the cell surface interact with the cationic complexes and enable the integration of complex into the cell endosome (Juliano et al., 2012; Lee et al., 2012). The delivery carriers are modified for improved cell internalization through modified surfaces (Nourbakhsh et al., 2015; Ly et al., 2017).

\subsection{Endosomal Escape: Release into the Cytosol}

Following the endocytosis and internalization of the siRNAcarrier complex into the cell, siRNA endosomal release is essential for degrading target mRNA in the cytoplasm. Often, this endosomal escape has been attributed to the proton sponge effect, which is caused by cationic molecules and results in endosome swelling and disruption (Dominska and Dykxhoorn, 2010). Recently, the release of siRNA from endosome has been recognized as an acute problem because, even upon successful systemic delivery into the cell, no efficient RNAi activity could be observed in some cases. Therefore, researchers are now focusing on how to quantitatively release siRNA into the cytosol through endosomal escape. Different classes of delivery agents have been devised to this end, such as cationic peptides, lipid nanoparticles, and polymers (Shrestha et al., 2012; Gilleron et al., 2013; Lechanteur et al., 2018). 
Please cite this article as

Chandela and Ueno, Reviews in Agricultural Science, 7:10-28, 2019

https://dx.doi.org/10.7831/ras.7.10

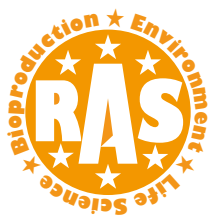

5. Advances with Carriers to Escape the Systemic Delivery Barriers

The basis for the design and selection of siRNA carriers solely depends on its physiochemical properties. The similar characteristics of siRNA to DNA provided the basis for conducting the initial trials using previously developed carriers for DNA. These carriers are broadly divided into two categories: viral and non-viral. Viral carriers possess high toxicity and are detrimental to the cell, hence, non-viral carriers have been extensively studied to replace them (Beilvert et al., 2012). Previous reviews have imparted basic information about such delivery carriers for siRNA therapeutics (Kanasty et al., 2013; Lee et al., 2016). Here, we will discuss the basis of their mechanisms and the advances in siRNA delivery by evading the obstacles.

\section{1. siRNA Bioconjugates}

Upon conjugation to siRNA, certain molecules have been shown to enhance siRNA stability, cellular uptake, and on-target delivery. These can be collectively categorized as bioconjugates, each with differing features (Fig. 4). Examples of bioconjugates that have been extensively utilized recently are cholesterol, $\mathrm{N}$-acetyl-galactosamine (GalNAc), aptamers, and antibodies.

\subsubsection{Cholesterol Bioconjugates}

The basis of introducing cholesterol for siRNA delivery relates to its importance as a structural component of the animal cell membrane. The presence of cholesterol promotes intracellular transport and has been found to provide nuclease resistance during siRNA delivery. Two cationic cholesterol derivatives, cholesteryloxypropan-1-amine (COPA) and cholesteryl-2- aminoethylcarbamate (CAEC) have been reported for liposomebased, stability-enhanced siRNA delivery (Han et al., 2008). Other reports have also shown cationic cholesterol-modified nanoparticles as the carriers for delivery of siRNA into tumor cells (Kadengodlu et al., 2013; Hattori et al., 2015).The interaction between cholesterol and serum apolipoproteins and the subsequent recognition by hepatocyte receptors has been utilized in the development of a biomimetic nanovector for the targeted delivery of cholesterol-conjugated siRNA (Ding et al., 2012). Chol-siRNAloaded rHDL nanoparticles were found to have efficient cellular uptake and targeted cytoplasmic delivery in human hepatocellular carcinoma cell lines. Modification of the passenger and guide siRNA strands with a cholesteryl moiety to exploit the interaction with recombinant human serum albumin (rHSA) revealed a 4- and a 6-fold increase in plasma life with single and double cholesteryl modifications in vivo, respectively (Bienk et al., 2016). Cholesterol-conjugated siRNAs have also been examined for carrier-free gene silencing of MDR1 (multi-drug resistance) genes (Chernikov et al., 2017). The ability of cholesterol to circulate through blood vessels helps in guided systemic delivery of siRNA to the liver and conjugation with this moiety have shown a successful application in numerous case (Ming and Laing, 2015; Sebestyén et al., 2015; Khan et al., 2016).

\subsubsection{Aptamer Bioconjugates}

siRNA-chimeras represent an extensive RNA-mediated approach for targeted delivery. Protein-binding RNAs are initially identified with the systematic evolution of ligands by exponential enrichment (SELEX) and conjugated to siRNA. The delivery is facilitated by the interaction of these aptamers with membrane
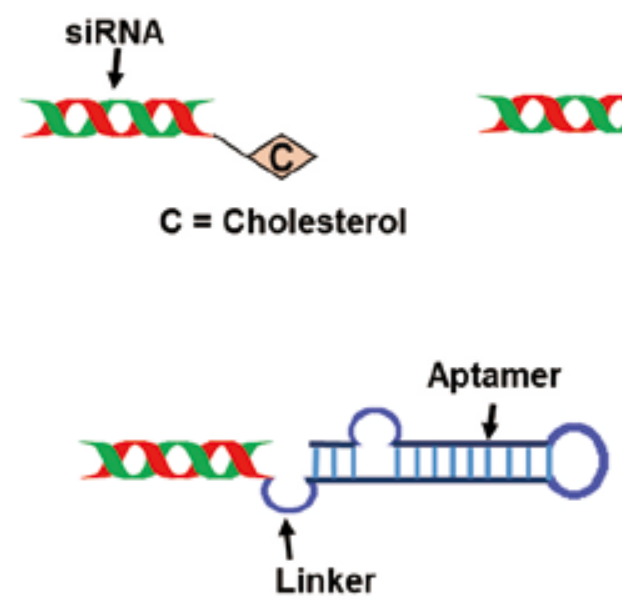
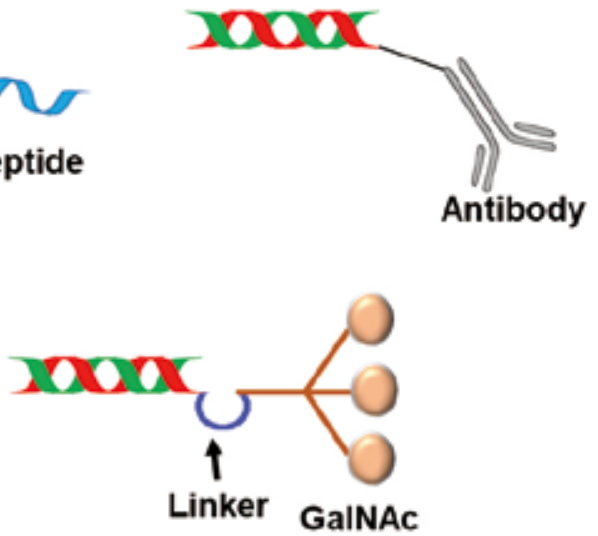

Fig.4 Bio-conjugate carrier systems for siRNA delivery. 
proteins. Prior reports have stated cell-specific targeted delivery using such aptamer-siRNA chimeras for prostate cancer cells and tumor vascular endothelial cells overexpressing PSMA, a cell surface receptor (McNamara et al., 2006). Evidence for the dual activity of such carriers, such as the inhibition of HIV replication by the aptamer and the target mRNA degradation by the anti-HIV siRNA. (Zhou et al., 2008, 2011). HER2 aptamerBcl-2 siRNA conjugates selectively internalized into HER2+ cells and silenced Bcl-2 gene expression (Thiel et al., 2012; Li et al., 2013). Aptamer AS1411 has shown specific binding to cell surface receptors and complexation with a cationic liposome improved intracellular trafficking to target the BRAF gene in melanomas (Li et al., 2014). This gene mutation is found in nearly $60 \%$ of malignant melanomas, which are difficult to treat. A recent review concerning aptamer-siRNA chimeras can be referred to for recent developments (Kruspe and Giangrande, 2017). Hence, this method of delivery improves intracellular delivery with enhanced interaction with membrane-bound proteins.

\subsubsection{Cell Penetrating Peptides}

Cell-penetrating peptides (CPPs), cationic, amphipathic peptides less than 30 amino acids in length, has emerged as a vital carrier for the transport of siRNA and other drugs across the cell membrane. CPP-siRNA complexes are non-covalently bonded, arising from electrostatic interactions that neutralize the anionic nature of siRNA to yield an overall cationic complex (Meade and Dowdy, 2007). These complexes provide an overall positive charge which helps in permeating through the cell membrane and have also been found helpful in the endosomal escape. Synthetic polypeptide, PVBLG(n)-8, was reported to have a helical structure assisting in amplified cellular uptake by destabilizing the cell membrane (Gabrielson et al., 2012). Amphipathic peptides consisting of lysine and arginine have been evaluated for efficient delivery of siRNA, as well as histidine-rich peptides have also shown enhanced intracellular trafficking with these cellpenetrating peptides (Crombez et al., 2009; Langlet-Bertin et al., 2010; Bartz et al., 2011; Kichler et al., 2013). Octaarginine (R8)modified lipid nanoparticles have been reported for increased gene silencing, blood circulation, and liver-specific distribution and accumulation in vivo (Hayashi et al., 2011; Chu et al., 2015).

The CPP TAT has been extensively utilized for the cellspecific delivery of siRNA. The anti-cancerous drug camptothecin was attached to TAT to effectively kill cancer cells through membrane disruption (Fang et al., 2013; Song et al., 2015). Methoxypolyethylene glycol-polycaprolactone (MPEG-PCL)conjugated $\mathrm{CPP}\left(\mathrm{CH}_{2} \mathrm{R}_{4} \mathrm{H}_{2} \mathrm{C}\right)(\mathrm{C}$, cysteine [Cys]; $\mathrm{H}$, histamine [His]; R, arginine [Arg]), when complexed with siRNA, resulted in augmented uptake, early endosomal escape, and facile cytosol release from the complex (Tanaka et al., 2013). Myristic acid conjugated to a CPP with a transferrin binding receptor peptide has shown targeted delivery of siRNA to brain cells through encapsulation (Youn et al., 2014). Cationic liposomes encapsulated the siRNA and the surface is modified with photolabile-caged CPP and asparagine-glycine-arginine peptide (NGR). NGR guided these inactive particles to CD13+ tumor cells where near-infrared (NIR) light illumination activated them by uncaging the lysine from the photosensitive groups (Yang et al., 2015). Cyclic RGD (cRGD) has provided extensive systemic siRNA delivery both in vitro and in vivo (Khatri et al., 2014; Liu et al., 2014; Huang et al., 2015; He et al., 2017; Zhou et al., 2017).

\subsubsection{Antibody Bioconjugates}

Antibody-conjugated siRNAs have been an ideal candidate to eliminate off-target effects by mediating cell-specific delivery with an affinity towards the respective antigen. HIV suppression was achieved in humanized mice through conjugation of a CD7 specific single-chain antibody to an oligo-9-arginine peptide for T-cell specific delivery and further, conjugated to chitosan and siRNA nanoparticles, to show enhanced association with the CD4 T-cell line as well as improved gene silencing (Kumar et al., 2008; Lee et al., 2012). Conjugation of anti-STAT siRNA through non-covalent interaction with a monoclonal antibody against Lewis-Y, an antigen expressed in cancer cells, yielded better silencing activity with targeted delivery than seen with a covalently linked vehicle (Ma et al., 2011).

Tumor-specific antibody addition to liposome-polycationDNA (LPD)-based carriers created TLPD nanocarriers for breast cancer therapy with enhanced binding affinity and gene silencing both in vitro and in vivo (Gao et al., 2011). Augmented HER2 mRNA and protein silencing was also reported using antibodypolymer conjugates (APCs), with aminooxy-derivatized cationic block polymer conjugated to an anti-HER2 Fab (Lu et al., 2013). Endosome-disruptive biotinylated polymers complexed with streptavidin-conjugated HER2 antibody were found to silence protein expression in breast and ovarian cancer cells (PalancaWessels et al., 2016). Antibody-conjugated carriers present great possibilities for effective siRNA delivery (Bäumer et al., 2017).

\subsubsection{GalNAc Bioconjugates}

GalNAc binds to asialoglycoprotein receptors that are highly expressed on hepatocytes and guides siRNA for targeted delivery to the liver. Nair and colleagues reported that siRNA conjugated with GalNAc showed 5-fold higher gene silencing in the liver. Later reports stated use of a non-nucleoside linker with monovalent units to develop trivalent GalNAc-conjugated oligonucleotides, which mimicked the activity of the parent trivalent GalNAc conjugates and elicited robust gene silencing in vivo (Nair et al., 2014; Rajeev 
Please cite this article as

Chandela and Ueno, Reviews in Agricultural Science, 7:10-28, 2019

https://dx.doi.org/10.7831/ras.7.10

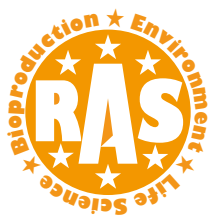

et al., 2015). Alnylam Pharmaceuticals conducted Phase 1 trials of Resuviran, an RNAi-based drug for ATTR amyloidosis treatment with GalNAc-mediated delivery. The target protein, transthyretin, displayed reduced levels up to $90 \%$ with multiple subcutaneous doses (Zimmermann et al., 2017). Their high receptor-specific delivery provides unaltered silencing activity even with a $50 \%$ reduction in receptor expression (Willoughby et al., 2018). Although these classes of delivery agents have been efficient for targeted delivery, rat hepatotoxicity renders them not able to advance into clinical development. This has been attributed to off-target effects and can be corrected with chemical modifications in the siRNA seed region with more thermally destabilizing nucleosides (Janas et al., 2018).

\subsection{Nanoparticle-Based Carriers}

The nanoparticle carrier systems can be broadly divided on the basis of their compositional unit into two groups i.e. organic and inorganic nanoparticles. Liposomes, micelles and lipid nanoparticles comprise the organic group whereas gold nanoparticles and quantum dots belong to the inorganic class (Fig. 5).

\subsubsection{Organic Nanoparticles}

Liposomes and lipid-based carrier systems have already been employed in the delivery of oligonucleotides due to similar architecture like a cell membrane. Many clinical trials have been done using lipid-based carrier systems. siRNAs are complexed with these carrier systems either encapsulated or surface immobilized and easily delivered inside the cell. Lipidcoated calcium phosphate nanoparticles (LCP NP) emerged as the successor of liposome-polycation-DNA (LPD) owing to the biodegradable core and highly negligible immunotoxicity. LCP NP has been found to efficiently inhibit lung metastasis in B16F10 melanoma cells with targeted delivery. The treatment increased the mean survival time of the animals by around $30 \%$ in comparison to the control group (Li et al., 2010; Yang et al., 2012).

A multifunctional envelope-type nano device (MEND) was utilized for PEG-peptide-dioleoyl phosphatidylethanolamine (DOPE) ternary conjugate (PPD) delivery with enhanced cellular uptake and endosomal escape. Further, higher silencing was observed with PPD-MEND co-modified PEG-distearoylphosph atidylethanolamine (DSPE) with no evidence of hepatotoxicity or an innate immune response (Hatakeyama et al., 2011). Stable nucleic acid lipid particles (SNALPs) complex provided efficient transport across the cell membrane when compared to the widely used polycationic carrier linear polyethyleneimine (Kong et al., 2012). A small lipid nanoparticle (SLNP) and mono argininecholesterol (MA-Chol) complex assembled by direct attachment via a single arginine on the cholesterol revealed a high level of gene knockdown in vitro, whereas in vivo experiments displayed elevated gene silencing and enhanced tumor localization of siRNA (Lee et al., 2016). Temperature responsive polymer-modified liposomes change from hydrophilic to hydrophobic above the lower critical solution temperature (LCST). Temperatures higher than the LCST enhanced their delivery into the cell and higher gene silencing with no cytotoxicity was reported (Wang et al., 2017). Low molecular weight chitosan-lipid nanoparticles (CS-LNPs) exhibited $40 \%$ gene knockdown and no significant cytotoxicity up to $500 \mu \mathrm{g} / \mathrm{mL}$ (Tezgel et al., 2018). Biocompatible gelatin based nanoparticles have also been reported to deliver polymerized siRNA with targeted administration (Lee et al., 2013).

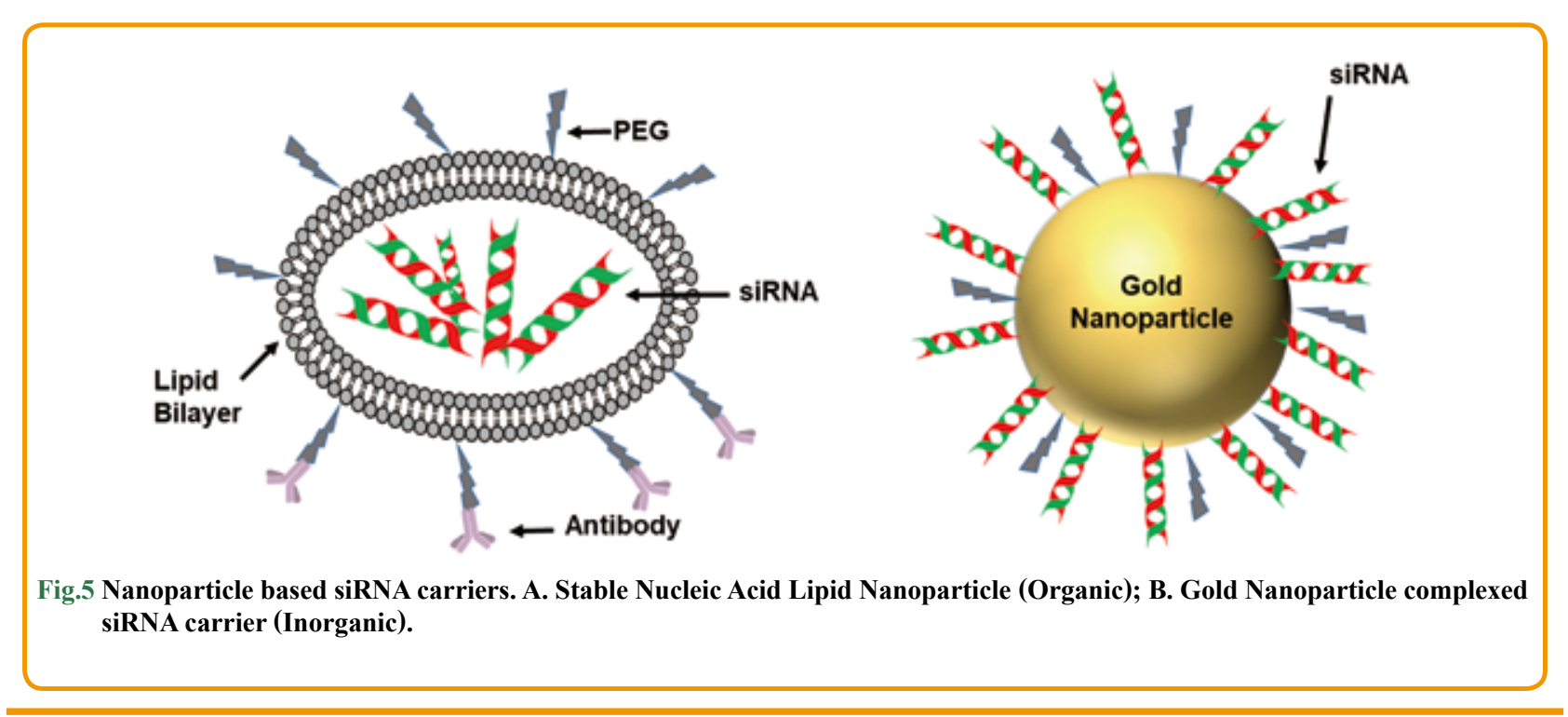




\subsubsection{Inorganic Nanoparticles}

Nanoparticles architecture with gold, magnetic ores, and other inorganic components have also gained importance with a different mechanism of cellular uptake. They either conjugate the siRNA covalently or encapsulate for intracellular delivery (Jiang et al., 2016). The gold nanoparticles have been surface immobilized with peptides and lipids for efficient delivery of these siRNA therapeutics. Whereas, the magnetic nanoparticles utilize their property to move under magnetic fields and get internalized into the cells through magnetofection. Polymer modified mesoporous silica nanoparticle have revealed targeted delivery in HER2+ breast cancers (Ngamcherdtrakul et al., 2015).

\subsection{Complexes as siRNA Delivery Carriers}

Cationic polymers have served as a great candidate for transfecting nucleic acids, such as siRNA, across the cell membrane (Fig. 6). The facile complexation of anionic nucleic acids with cationic polymers through electrostatic interactions helps charge neutralization, shield from degradation and improve cell uptake. These complexes have been found to be nuclease resistant (Wagner, 2012; Amjad et al., 2017). Poly-L-lysine, polyethyleneimine (PEI), and poly-D,L-lactide-co-glycolide (PLGA) have gained importance owing to their upregulated transport through the cell membrane (Nimesh, 2012; Ragelle et al., 2013). Encapsulation of $\mathrm{PEI} / \mathrm{siRNA}$ polyplexes with (DexS/pARG) ${ }_{5}$ created degradable capsular structures with better gene silencing in HeLa cells (Ganas et al., 2014). Linear PEI nanoparticles (LPN) showed improved silencing in vitro and in vivo (Goyal et al., 2012). Co-delivery of siRNA and hypericin to hypoxic human nasopharyngeal carcinoma cells by hyaluronic acid-modified PLGA-PEI nanoparticles showed improved accumulation in the tumor due to increased permeability and retention. Bioreducible polymer based targeted delivery of
siRNA have also been revealed for human cancer gene therapy (Xia and Lin, 2012; Kozielski et al., 2014). Recent reports have shown co-delivery of siRNA and plasmid DNA using novel PEI/ poly- $\gamma$-glutamic acid nanoparticles (Li et al., 2016; Peng et al., 2017). PLGA-PLL biodegradable nanoparticles exhibited controlled release, efficient gene silencing, endosomal escape, siRNA potency, and resistance against nuclease degradation (Zhou et al., 2012). Targeted systemic delivery has also been achieved with other polymeric micelles (Xiong et al., 2010; Liu et al., 2013; Jhaveri and Torchilin, 2014). HER2+ breast cancer has also been targeted with siRNA using cationic polymer-modified silica nanoparticles (Ngamcherdtrakul et al., 2015; Barrett and Guidry, 2016).

Dendrimers have been a vital addition to the category of siRNA carriers. They are small, compact and cationic in nature, providing a strong binding affinity of siRNA for transfer into the cell. They impart non-toxic delivery of siRNA with a significant increase in silencing activity (Biswas and Torchilin, 2013; Wu et al., 2013; Liu and Peng, 2016). Cationic poly (amidoamine) (PAMAM) and poly(propyleneimine) (PPI) are two common dendrimer systems employed in the targeted delivery of siRNA (Taratula et al., 2009; Kesharwani et al., 2015). PEG-modified PAMAM dendrimers displayed improved resistance against nucleases and gave high transfection efficiency, in vitro gene knockdown similar to Lipofectamine 2000-mediated transfection (Tang et al., 2012). Similarly, triethanolamine-modified PAMAM dendrimers showed gene silencing in prostate cancer cells and arginine-modified dendrimers showed prominent drug delivery in vitro and in vivo (Liu et al., 2012, 2014). PAMAM-PEG-peptide dendriplex with gene-specific peptides were incorporated using a PEG linker and the resulting gene silencing was significantly enhanced. In addition, these dendriplexes were non-toxic, with a cell viability of approximately $75 \%$ (Urbiola et al., 2018).
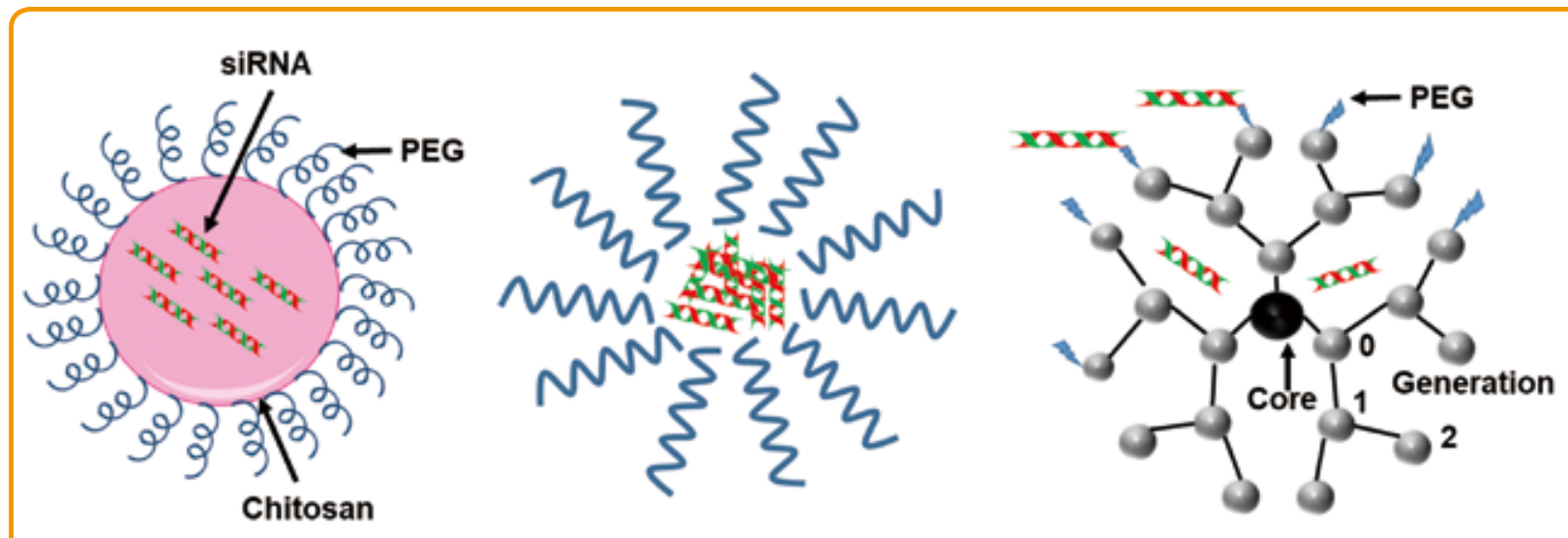

Fig.6 Polymer complex based siRNA carrier systems. A. Chitosan complexed siRNA; B. Polyelectrolyte miceller complex ; C. Dendrimer. 
Please cite this article as

Chandela and Ueno, Reviews in Agricultural Science, 7:10-28, 2019

https://dx.doi.org/10.7831/ras.7.10

Table 1. Examples of human diseases targeted with siRNA-mediated RNAi.

\begin{tabular}{lll}
\hline \multicolumn{1}{c}{ Disease } & \multicolumn{1}{c}{ Target } & \multicolumn{1}{c}{ Reference } \\
\hline Age-related Macular Degeneration & Vascular endothelial growth factor & (Garba and Mousa, 2010) \\
\hline Acute Kidney Injury & P53 & (Molitoris et al., 2009) \\
\hline Colorectal Cancer with Hepatic Metastases & Macrophage migration inhibitory factor & (He, 2017) \\
\hline Glaucoma & B2 adrenergic receptor & (Martínez et al., 2014) \\
\hline Dry Eye Disease & Transient Receptor Potential Vanilloid 1 & (Moreno-Montañés et al., 2018) \\
\hline Chronic Myeloid Leukemia & BCR-ABL gene & (Valencia-Serna et al., 2014) \\
\hline Hepatocellular Carcinoma & Kinetochore-associated protein 2 & (Makita et al., 2017) \\
\hline Hypercholesterolemia & Pproprotein convertase subtilisin-kexin type 9 & (Kosmas et al., 2018) \\
\hline Pachyonychia Congenita & Keratin 6a & (Leachman et al., 2008) \\
\hline Primary Hyperoxaluria Typel (PH1) & Alanine-glyoxylate aminotransferase & (Liebow et al., 2017)
\end{tabular}

Table 2. Major siRNA therapeutics in Clinical trials for humans.

\begin{tabular}{|c|c|c|c|c|c|c|}
\hline Drug & Target & Vehicle & Condition & Participants & Phase/Status & $\begin{array}{c}\text { Investigator } \\
\text { (Reference) }\end{array}$ \\
\hline TKM-080301 & Polo-kinase-1 & SNALP & $\begin{array}{c}\text { Cancer } \\
\text { Neuroendocrine } \\
\text { Tumors } \\
\text { Adrenocortical } \\
\text { Carcinoma }\end{array}$ & 68 & I, II/Completed & $\begin{array}{c}\text { Arbutus Biopharma } \\
\text { Corporation, } \\
\text { United States } \\
\text { (Demeure et al., 2016) }\end{array}$ \\
\hline AGN211745 & VEGFR1 & $\mathrm{NC}$ & $\begin{array}{c}\text { Choroid } \\
\text { Neovascularization } \\
\text { AMD } \\
\end{array}$ & 138 & II/Terminated & $\begin{array}{l}\text { Allergan, Ireland } \\
\text { (Barakat and Kaiser, } \\
\text { 2009) }\end{array}$ \\
\hline ALN-PCS02 & PCSK9 & SNALP & $\begin{array}{l}\text { Elevated LDL- } \\
\text { Cholesterol }\end{array}$ & 32 & I/Completed & $\begin{array}{c}\text { Alnylam } \\
\text { Pharmaceuticals, } \\
\text { United States } \\
\text { (Fitzgerald } \text { et al., 2014) }\end{array}$ \\
\hline ALN-RSV01 & RSV-N Gene & - & $\begin{array}{l}\text { Respiratory Syncytial } \\
\text { Virus Infections }\end{array}$ & 87 & II/Completed & $\begin{array}{c}\text { Alnylam } \\
\text { Pharmaceuticals, } \\
\text { United States (J. et al., } \\
\text { 2016) }\end{array}$ \\
\hline ALN-TTR01 & TTR & LNP & $\begin{array}{c}\text { Transthyretin mediated } \\
\text { Amyloidosis }\end{array}$ & 32 & II/Completed & $\begin{array}{c}\text { Alnylam } \\
\text { Pharmaceuticals, } \\
\text { United States (Coelho } \\
\text { et al., 2011) }\end{array}$ \\
\hline ALN-TTRSC & TTR & siRNA-GalNAc & Acute Kidney Injury & 341 & II/Completed & $\begin{array}{c}\text { Alnylam } \\
\text { Pharmaceuticals, } \\
\text { United States (T. et al., } \\
\text { 2013) }\end{array}$ \\
\hline
\end{tabular}


Please cite this article as Chandela and Ueno, Reviews in Agricultural Science, 7:10-28, 2019 https://dx.doi.org/10.7831/ras.7.10

\begin{tabular}{|c|c|c|c|c|c|c|}
\hline Drug & Target & Vehicle & Condition & Participants & Phase/Status & $\begin{array}{l}\text { Investigator } \\
\text { (Reference) }\end{array}$ \\
\hline Atu027 & PKN3 & $\begin{array}{l}\text { Cationic } \\
\text { lipoplex }\end{array}$ & $\begin{array}{c}\text { Advanced Solid } \\
\text { Tumors }\end{array}$ & 34 & I/Completed & $\begin{array}{l}\text { Silence Therapeutics } \\
\text { GmbH, Germany } \\
\text { (Strumberg et al., 2011) }\end{array}$ \\
\hline Atu027-I-02 & PKN3 & $\begin{array}{l}\text { Cationic } \\
\text { lipoplex }\end{array}$ & $\begin{array}{c}\text { Metastatic } \\
\text { Pancreatic Cancer }\end{array}$ & 29 & II/Completed & $\begin{array}{c}\text { Silence Therapeutics } \\
\text { GmbH, Germany } \\
\text { (Schultheis et al., 2016) }\end{array}$ \\
\hline Bevasiranib & VEGF & $\mathrm{NC}$ & $\begin{array}{l}\text { Age-related } \\
\text { macular } \\
\text { degeneration } \\
\text { (AMD) }\end{array}$ & 338 & III/Terminated & $\begin{array}{l}\text { Opko Health Inc., } \\
\text { United States (Garba } \\
\text { and Mousa, 2010) }\end{array}$ \\
\hline CALAA-01 & RRM2 & $\begin{array}{c}\text { CyD NP, } \\
\text { transferrin, PEG }\end{array}$ & $\begin{array}{c}\text { Cancer Solid } \\
\text { Tumors }\end{array}$ & 24 & $\mathrm{I} /$ Terminated & \begin{tabular}{|c|} 
Calando \\
Pharmaceuticals, United \\
States (Zuckerman et al., \\
2014)
\end{tabular} \\
\hline PF-04523655 & RTP801 & $\mathrm{NC}$ & $\begin{array}{c}\text { Choroidal } \\
\text { Neovascularization } \\
\text { Diabetic } \\
\text { Retinopathy } \\
\text { Diabetic Macular } \\
\text { Edema }\end{array}$ & 258 & II/Completed & $\begin{array}{l}\text { Quark Pharmaceuticals, } \\
\text { Israel (Nguyen et al., } \\
\text { 2012) }\end{array}$ \\
\hline QPI-1002 & P53 & $\mathrm{NC}$ & $\begin{array}{l}\text { Acute Kidney } \\
\text { Injury }\end{array}$ & 1088 & III/Recruiting & $\begin{array}{c}\text { Quark Pharmaceuticals, } \\
\text { Israel (Demirjian et al., } \\
\text { 2017) }\end{array}$ \\
\hline
\end{tabular}

CyD: cyclodextrin, GalNAc, $N$-acetylgalactoseamine, KSP: kinesin spindle protein, LNP: lipid nanoparticle, RRM2: M2 subunit of ribonucleotide reductase, NC: no carrier, PEG: polyethylene glycol, PCSK9: proprotein convertase subtilisin/kexin type 9, PKN3: protein kinase N3, RSV-N gene: respiratory syncytial virus nucleocapsid gene, SNALP: stable nucleic-acid lipid particles, TTR: transthyretin, VEGF: vascular endothelial growth factor

Complexation of siRNA with PAMAM, via a tadpole dendrimer structure conjugated to a peptide through PEG linker, significantly indicated specific gene knockdown over 3 days of administration in mice (Liu et al., 2013). Maltose-modified poly (propyleneimine) dendrimers have been employed with specific conjugated antibodies for cell-specific delivery, coupled with efficient delivery using polyplexes. (Tietze et al., 2017).

\section{Current Clinical Trials}

With advanced research and extensive efforts in formulating nucleic acid-based therapeutics, siRNA treatment has been studied for various diseases (Table 1). Bevasiranib was the first siRNAbased drug to enter the clinical trials for the treatment of agerelated macular degeneration (AMD) (Garba and Mousa, 2010). Drugs targeting the RTP801 gene are also for the treatment of AMD (Nguyen et al., 2012). Treatment for respiratory syncytial nasal virus infection was administered therapeutically in single and multiple dose regimens using the ALN-RSV01 conjugate (Alvarez et al., 2009). Acute renal failure and kidney injury have been evaluated as critical ailments after cardiac surgery. QPI-1002, a siRNA-based drug, has been analyzed for curing these problems (Demirjian et al., 2017). PCSK9 silencing using a siRNA drug significantly reduced the level of blood LDL cholesterol in healthy patients and provided evidence for their safe administration against hypercholesterolaemia (Fitzgerald et al., 2014). Cancer cells have been reported to overexpress VEGF; hence, siRNA drug targeting inhibition of this gene has notably demonstrated anticancerous activity with sufficient tolerance to the drug (Fitzgerald et al., 2017). Mutation in the transthyretin (TTR) gene results in elevated levels of amyloid and accumulation of these fibrils in various tissues results in heart failure, central nervous system breakdown, and postural hypotension (Rizk and Tüzmen, 2017). This drug already passed the clinical evaluation and approved by FDA as already mentioned in this review.

These are certain classified examples of siRNA-based drugs in clinical trials (Table 2). However, there are other drugs which are awaiting trial recruitment for investigating their action in disease treatment. Therefore, this field provides enormous potential 
Please cite this article as

Chandela and Ueno, Reviews in Agricultural Science, 7:10-28, 2019

https://dx.doi.org/10.7831/ras.7.10

to extend new domains into genetic therapeutics for numerous undruggable targets.

\section{Conclusions}

The current developments with therapeutic siRNAs provide many researchers with the scope to utilize this technological tool for effective gene suppression in critical diseases with desired modifications and very soon these drugs will significantly translate into clinical application. Although, lipid based systems have been the initial strategy, now numerous systems play an important role in targeted delivery of siRNAs. At present, it is the combinatorial formulations with different carrier systems which provides the effective systemic delivery of siRNAs. Unique mode of action of each delivery system helps in overcoming the various barriers. They possess all the characteristics at the nanoscale, required for the systemic administration of nucleic acid drugs. The current development with the approval of Onpatro drug by the FDA has provided researchers with the belief of efficiently translating siRNA drugs for clinical application with improved carrier systems. Additionally, RNAi tool have also gained importance as a promising tool for gene regulation in plants also. Advanced breeding technologies are utilizing this tool for creating disease resistant plants or insect resistant plants (Younis et al., 2014; Mamta et al., 2016). Hence, in addition to the mammalian targets, this technological development will also bring reform in the agriculture sector.

\section{REFERENCES}

Adams, D., Gonzalez-Duarte, A., O’Riordan, W.D., Yang, C.-C., Ueda, M., Kristen, A. V., Tournev, I., Schmidt, H.H., Coelho, T., Berk, J.L., et al. 2018. Patisiran, an RNAi Therapeutic, for Hereditary Transthyretin Amyloidosis. N. Engl. J. Med. 379: 11-21. Alvarez, R., Elbashir, S., Borland, T., Toudjarska, I., Hadwiger, P., John, M., Roehl, I., Morskaya, S.S., Martinello, R., Kahn, J., et al. 2009. RNA interference-mediated silencing of the respiratory syncytial virus nucleocapsid defines a potent antiviral strategy. Antimicrob. Agents Chemother. 53: 3952-3962.

Amjad, M.W., Kesharwani, P., Mohd Amin, M.C.I., and Iyer, A.K. 2017. Recent advances in the design, development, and targeting mechanisms of polymeric micelles for delivery of siRNA in cancer therapy. Prog. Polym. Sci. 64: 154-181.

Bao, Y., Jin, Y., Chivukula, P., Zhang, J., Liu, Y., Liu, J., Clamme, J.P., Mahato, R.I., Ng, D., Ying, W., et al. 2013. Effect of PEGylation on biodistribution and gene silencing of siRNA/ lipid nanoparticle complexes. Pharm. Res. 30: 342-351.

Barakat, M.R., and Kaiser, P. 2009. VEGF inhibitors for the treatment of neovascular age-related macular degeneration. Expert Opin. Investig. Drugs 18: 637-646.

Barrett, S.E., and Guidry, E.N. 2016. Liver-targeted SiRNA delivery using biodegradable poly (Amide) polymer conjugates. In: Shum K., Rossi J. (eds) SiRNA Delivery Methods. Methods in Molecular Biology, 1364: 11-25, Humana Press, New York, NY.

Bartz, R., Fan, H., Zhang, J., Innocent, N., Cherrin, C., Beck, S.C., Pei, Y., Momose, A., Jadhav, V., Tellers, D.M., et al. 2011. Effective siRNA delivery and target mRNA degradation using an amphipathic peptide to facilitate $\mathrm{pH}$-dependent endosomal escape. Biochem. J. 435: 475-487.

Bäumer, N., Berdel, W.E., and Bäumer, S. 2017. ImmunoproteinMediated siRNA Delivery. Mol. Pharm. 14: 1339-1351.

Beilvert, F., Mével, M., Châtin, B., and Pitard, B. 2012. Local siRNA delivery by non-viral vectors. J. Drug Deliv. Sci. Technol. 22: 17-27.

Bienk, K., Hvam, M.L., Pakula, M.M., Dagnæs-Hansen, F., Wengel, J., Malle, B.M., Kragh-Hansen, U., Cameron, J., Bukrinski, J.T., and Howard, K.A. 2016. An albumin-mediated cholesterol design-based strategy for tuning siRNA pharmacokinetics and gene silencing. J. Control. Release 232: 143-151.

Biswas, S., and Torchilin, V.P. 2013. Dendrimers for siRNA delivery. Pharmaceuticals 6: 161-183.

Bitko, V., and Barik, S. 2008. Nasal delivery of siRNA. Methods Mol.Biol. 442: 75-82.

Borna, H., Imani, S., Iman, M., and Azimzadeh Jamalkandi, S. 2015. Therapeutic face of RNAi: in vivo challenges. Expert Opin. Biol. Ther. 15: 269-85.

Chakraborty, C., Sharma, A.R., Sharma, G., Doss, C.G.P., and Lee, S.S. 2017. Therapeutic miRNA and siRNA: Moving from Bench to Clinic as Next Generation Medicine. Mol. Ther. Nucleic Acids 8: 132-143.

Chernikov, I. V., Gladkikh, D. V., Meschaninova, M.I., Ven' yaminova, A.G., Zenkova, M.A., Vlassov, V. V., and Chernolovskaya, E.L. 2017. Cholesterol-Containing NucleaseResistant siRNA Accumulates in Tumors in a Carrier-free Mode and Silences MDR1 Gene. Mol. Ther. - Nucleic Acids 6: 209-220.

Chu, D., Xu, W., Pan, R., Ding, Y., Sui, W., and Chen, P. 2015. Rational modification of oligoarginine for highly efficient siRNA delivery: Structure-activity relationship and mechanism of intracellular trafficking of siRNA. Nanomedicine Nanotechnology, Biol. Med. 11: 435-446.

Coelho, T., Suhr, O.B., Adams, D., Lozeron, P., Hawkins, P., Mant, T., Stangou, A., Hutabarat, R., Rossomando, A., Butler, J., et al. 2011. Interim clinical update for ALN-TTR01, a novel RNAI therapeutic for the treatment of transthyretin amyloidosis. $J$. Peripher. Nerv. Syst. 16: S25-S26.

Crombez, L., Aldrian-Herrada, G., Konate, K., Nguyen, Q.N., McMaster, G.K., Brasseur, R., Heitz, F., and Divita, G. 2009. A new potent secondary amphipathic cell-penetrating peptide for siRNA delivery into mammalian cells. Mol. Ther. 17: 95-103. 
Demeure, M.J., Armaghany, T., Ejadi, S., Ramanathan, R.K., Elfiky, A., Strosberg, J.R., Smith, D.C., Whitsett, T., Liang, W.S., Sekar, S., et al. 2016. A phase I/II study of TKM-080301, a PLK1-targeted RNAi in patients with adrenocortical cancer (ACC). J. Clin. Oncol. 34: 2547.

Demirjian, S., Ailawadi, G., Polinsky, M., Bitran, D., Silberman, S., Shernan, S.K., Burnier, M., Hamilton, M., Squiers, E., Erlich, S., et al. 2017. Safety and Tolerability Study of an Intravenously Administered Small Interfering Ribonucleic Acid (siRNA) Post On-Pump Cardiothoracic Surgery in Patients at Risk of Acute Kidney Injury. Kidney Int. Reports 2: 836-843.

Ding, Y., Wang, W., Feng, M., Wang, Y., Zhou, J., Ding, X., Zhou, X., Liu, C., Wang, R., and Zhang, Q. 2012. A biomimetic nanovector-mediated targeted cholesterol-conjugated siRNA delivery for tumor gene therapy. Biomaterials 33: 8893-8905.

Dominska, M., and Dykxhoorn, D.M. 2010. Breaking down the barriers: siRNA delivery and endosome escape. J. Cell Sci. 123: 1183-1189.

Elbashir, S.M., Harborth, J., Lendeckel, W., Yalcin, A., Weber, K., and Tuschl, T. 2001a. Duplexes of $21 \pm$ nucleotide RNAs mediate RNA interference in cultured mammalian cells. Nature 411: 494-498.

Elbashir, S.M., Lendeckel, W., and Tuschl, T. 2001b. RNA interference is mediated by 21 - and 22-nucleotide RNAs. Genes Dev. 15: 188-200.

Fang, B., Jiang, L., Zhang, M., and Ren, F.Z. 2013. A novel cellpenetrating peptide TAT-A1 delivers siRNA into tumor cells selectively. Biochimie 95: 251-257.

Finan, C., Gaulton, A., Kruger, F.A., Lumbers, R.T., Shah, T., Engmann, J., Galver, L., Kelley, R., Karlsson, A., Santos, R., et al. 2017. The druggable genome and support for target identification and validation in drug development. Sci. Transl. Med. 9 (383): eaag1166.

Fire, A. 1999. RNA-triggered gene silencing. Trends Genet. 15: 358-363.

Fire, A., Xu, S., Montgomery, M.K., Kostas, S.A., Driver, S.E., and Mello, C.C. 1998. Potent and specific genetic interference by double-stranded RNA in Caenorhabditis elegans. Nature 391: 806-811.

Fitzgerald, K., Frank-Kamenetsky, M., Shulga-Morskaya, S., Liebow, A., Bettencourt, B.R., Sutherland, J.E., Hutabarat, R.M., Clausen, V.A., Karsten, V., Cehelsky, J., et al. 2014. Effect of an RNA interference drug on the synthesis of proprotein convertase subtilisin/kexin type 9 (PCSK9) and the concentration of serum LDL cholesterol in healthy volunteers: A randomised, singleblind, placebo-controlled, phase 1 trial. Lancet 383: 60-68.

Fitzgerald, K., White, S., Borodovsky, A., Bettencourt, B.R., Strahs, A., Clausen, V., Wijngaard, P., Horton, J.D., Taubel, J.,
Brooks, A., et al. 2017. A Highly Durable RNAi Therapeutic Inhibitor of PCSK9. N. Engl. J. Med. 376: 41-51.

Frank, F., Sonenberg, N., and Nagar, B. 2010. Structural basis for 59 -nucleotide base-specific recognition of guide RNA by human AGO2. Nature 465: 818-822.

Gabrielson, N.P., Lu, H., Yin, L., Kim, K.H., and Cheng, J. 2012. A cell-penetrating helical polymer for siRNA delivery to mammalian cells. Mol. Ther. 20: 1599-1609.

Ganas, C., Weiß, A., Nazarenus, M., Rösler, S., Kissel, T., Rivera Gil, P., and Parak, W.J. 2014. Biodegradable capsules as nonviral vectors for in vitro delivery of PEI/siRNA polyplexes for efficient gene silencing. J. Control. Release 196: 132-138.

Gao, J., Liu, W., Xia, Y., Li, W., Sun, J., Chen, H., Li, B., Zhang, D., Qian, W., Meng, Y., et al. 2011. The promotion of siRNA delivery to breast cancer overexpressing epidermal growth factor receptor through anti-EGFR antibody conjugation by immunoliposomes. Biomaterials 32: 3459-3470.

Garba, A.O., and Mousa, S.A. 2010. Bevasiranib for the treatment of wet, age-related macular degeneration. Ophthalmol. Eye Dis. 2: $75-83$.

Garg, S.M., Falamarzian, A., Vakili, M.R., Aliabadi, H.M., Uludağ, H., and Lavasanifar, A. 2016. Polymeric micelles for MCL-1 gene silencing in breast tumors following systemic administration. Nanomedicine 11: 2319-2339.

Gilleron, J., Querbes, W., Zeigerer, A., Borodovsky, A., Marsico, G., Schubert, U., Manygoats, K., Seifert, S., Andree, C., Stöter, M., et al. 2013. Image-based analysis of lipid nanoparticlemediated siRNA delivery, intracellular trafficking and endosomal escape. Nat. Biotechnol. 31: 638-646.

Goyal, R., Tripathi, S.K., Tyagi, S., Sharma, A., Ram, K.R., Chowdhuri, D.K., Shukla, Y., Kumar, P., and Gupta, K.C. 2012. Linear PEI nanoparticles: Efficient pDNA/siRNA carriers in vitro and in vivo. Nanomedicine Nanotechnology, Biol. Med. 8: 167-175. Gresham, D. 2003. RNAi on or off target? Nat. Genet. 34: 133.

Gujrati, M., and Lu, Z.R. 2013. Targeted Systemic Delivery of Therapeutic siRNA In: Gene Therapy of Cancer: Translational Approaches from Preclinical Studies to Clinical Implementation: Third Edition. pp. 47-65.

Gvozdeva, O. V., Gladkih, D. V., Chernikov, I. V., Meschaninova, M.I., Venyaminova, A.G., Zenkova, M.A., Vlassov, V. V., and Chernolovskaya, E.L. 2018. Nuclease-resistant 63-bp trimeric siRNAs simultaneously silence three different genes in tumor cells. FEBS Lett. 592: 122-129.

Hammond, S.M., Caudy, A.A., and Hannon, G.J. 2001. Posttranscriptional gene silencing by double-stranded RNA. Nat. Rev. Genet. 2: 110-119.

Han, S.E., Kang, H., Shim, G.Y., Suh, M.S., Kim, S.J., Kim, J.S., and Oh, Y.K. 2008. Novel cationic cholesterol derivative- 
Please cite this article as

Chandela and Ueno, Reviews in Agricultural Science, 7:10-28, 2019

https://dx.doi.org/10.7831/ras.7.10

based liposomes for serum-enhanced delivery of siRNA. Int. J. Pharm. 353: 260-269.

Haraszti, R.A., Miller, R., Didiot, M.C., Biscans, A., Alterman, J.F., Hassler, M.R., Roux, L., Echeverria, D., Sapp, E., DiFiglia, M., et al. 2018. Optimized Cholesterol-siRNA Chemistry Improves Productive Loading onto Extracellular Vesicles. Mol. Ther. 26: 1973-1982.

Hatakeyama, H., Akita, H., Ito, E., Hayashi, Y., Oishi, M., Nagasaki, Y., Danev, R., Nagayama, K., Kaji, N., Kikuchi, H., et al. 2011. Systemic delivery of siRNA to tumors using a lipid nanoparticle containing a tumor-specific cleavable PEG-lipid. Biomaterials 32: 4306-4316.

Hattori, Y., Hara, E., Shingu, Y., Minamiguchi, D., Nakamura, A., Arai, S., Ohno, H., Kawano, K., Fujii, N., and Yonemochi, E. 2015. SiRNA delivery into tumor cells by cationic cholesterol derivative-based nanoparticles and liposomes. Biol. Pharm. Bull. 38: 30-38.

Haussecker, D. 2014. Current issues of RNAi therapeutics delivery and development. J. Control. Release 195: 49-54.

Hayashi, Y., Yamauchi, J., Khalil, I.A., Kajimoto, K., Akita, H., and Harashima, H. 2011. Cell penetrating peptide-mediated systemic siRNA delivery to the liver. Int. J. Pharm. 419: 308-313.

He, S., Cen, B., Liao, L., Wang, Z., Qin, Y., Wu, Z., Liao, W., Zhang, Z., and Ji, A. 2017. A tumor-targeting cRGD-EGFR siRNA conjugate and its anti-tumor effect on glioblastoma in vitro and in vivo. Drug Deliv. 24: 471-481.

He, X.-X. 2017. Macrophage migration inhibitory factor siRNA inhibits hepatic metastases of colorectal cancer cells. Front. Biosci. 22: 4549.

Huang, L., and Guo, S. 2011. Nanoparticles escaping RES and endosome: Challenges for siRNA delivery for cancer therapy. $J$. Nanomater. 2011: 742895, doi: 10.1155/2011/742895.

Huang, Y., Wang, X., Huang, W., Cheng, Q., Zheng, S., Guo, S., Cao, H., Liang, X.J., Du, Q., and Liang, Z. 2015. Systemic Administration of siRNA via cRGD-containing Peptide. Sci. Rep. 5: 12458, doi: 10.1038/srep12458.

Gottlieb J., Zamora M.R., Hodges T., Musk A.W., Sommerwerk U., Dilling D., Arcasoy S., DeVincenzo J., Karsten V., Shah S., Bettencourt B. R., Cehelsky J., Nochur S., Gollob J., Vaishnaw A., Simon A. R., Glanville A. R. 2016. ALN-RSV01 for prevention of bronchiolitis obliterans syndrome after respiratory syncytial virus infection in lung transplant recipients. J. Hear. Lung Transplant. 35: 213-221.

Janas, M.M., Schlegel, M.K., Harbison, C.E., Yilmaz, V.O., Jiang, Y., Parmar, R., Zlatev, I., Castoreno, A., Xu, H., ShulgaMorskaya, S., et al. 2018. Selection of GalNAc-conjugated siRNAs with limited off-Target-driven rat hepatotoxicity. Nat. Commun. 9 (1): 723, doi: 10.1038/s41467-018-02989-4.
Jhaveri, A.M., and Torchilin, V.P. 2014. Multifunctional polymeric micelles for delivery of drugs and siRNA. Front. Pharmacol. 5: 77, doi: 10.3389/fphar.2014.00077.

Jiang, Y., Huo, S., Hardie, J., Liang, X.-J., and Rotello, V.M. 2016. Progress and perspective of inorganic nanoparticle-based siRNA delivery systems. Expert Opin. Drug Deliv. 13: 547-559.

Juliano, R.L., Ming, X., and Nakagawa, O. 2012. Cellular uptake and intracellular trafficking of antisense and siRNA oligonucleotides. Bioconjug. Chem. 23: 147-157.

Kadengodlu, P.A., Aigaki, T., Abe, H., and Ito, Y. 2013. Cationic cholesterol-modified gelatin as an in vitro siRNA delivery vehicle. Mol. Biosyst. 9: 965.

Kanasty, R., Dorkin, J.R., Vegas, A., and Anderson, D. 2013. Delivery materials for siRNA therapeutics. Nat. Mater. 12: 967-977.

Kesharwani, P., Banerjee, S., Gupta, U., Cairul, M., Mohd, I., Padhye, S., Sarkar, F.H., and Iyer, A.K. 2015. PAMAM dendrimers as promising nanocarriers for RNAi therapeutics. Biochem. Pharmacol. 18: 565-572.

Khairuddin, N., Gantier, M.P., Blake, S.J., Wu, S.Y., Behlke, M.A., Williams, B.R., and McMillan, N.A. 2012. SiRNA-induced immunostimulation through TLR7 promotes antitumoral activity against HPV-driven tumors in vivo. Immunol. Cell Biol. 90: $187-196$.

Khan, T., Weber, H., Dimuzio, J., Matter, A., Dogdas, B., Shah, T., Thankappan, A., Disa, J., Jadhav, V., Lubbers, L., et al. 2016. Silencing Myostatin Using Cholesterol-conjugated siRNAs Induces Muscle Growth. Mol. Ther. - Nucleic Acids 5 (8): e342, doi: 10.1038/mtna.2016.55.

Khatri, N., Baradia, D., Vhora, I., Rathi, M., and Misra, A. 2014. CRGD grafted liposomes containing inorganic nano-precipitate complexed siRNA for intracellular delivery in cancer cells. $J$. Control. Release 182: 45-57.

Kichler, A., Mason, A.J., Marquette, A., and Bechinger, B. 2013. Histidine-rich cationic amphipathic peptides for plasmid DNA and siRNA delivery. Methods Mol. Biol. 948: 85-103.

Kong, W.H., Bae, K.H., Jo, S.D., Kim, J.S., and Park, T.G. 2012. Cationic lipid-coated gold nanoparticles as efficient and noncytotoxic intracellular siRNA delivery vehicles. Pharm. Res. 29: $362-374$.

Kosmas, C., Muñoz Estrella, A., Sourlas, A., Silverio, D., Hilario, E., Montan, P., and Guzman, E. 2018. Inclisiran: A New Promising Agent in the Management of Hypercholesterolemia. Diseases 6: 63.

Kozielski, K.L., Tzeng, S.Y., and Green, J.J. 2013. Bioengineered nanoparticles for siRNA delivery. Wiley Interdiscip. Rev. Nanomedicine Nanobiotechnology 5: 449-468.

Kozielski, K.L., Tzeng, S.Y., Hurtado De Mendoza, B.A., and Green, J.J. 2014. Bioreducible cationic polymer-based 
nanoparticles for efficient and environmentally triggered cytoplasmic siRNA delivery to primary human brain cancer cells. ACS Nano 8: 3232-3241.

Kruspe, S., and Giangrande, P. 2017. Aptamer-siRNA Chimeras: Discovery, Progress, and Future Prospects. Biomedicines 5: 45.

Ku, S.H., Jo, S.D., Lee, Y.K., Kim, K., and Kim, S.H. 2016. Chemical and structural modifications of RNAi therapeutics. Adv. Drug Deliv. Rev. 104: 16-28.

Kumar, P., Ban, H.S., Kim, S.S., Wu, H., Pearson, T., Greiner, D.L., Laouar, A., Yao, J., Haridas, V., Habiro, K., et al. 2008. T Cell-Specific siRNA Delivery Suppresses HIV-1 Infection in Humanized Mice. Cell 134: 577-586.

Langlet-Bertin, B., Leborgne, C., Scherman, D., Bechinger, B., Mason, A.J., and Kichler, A. 2010. Design and evaluation of histidine-rich amphipathic peptides for siRNA delivery. Pharm. Res. 27: 1426-1436.

Leachman, S.A., Hickerson, R.P., Hull, P.R., Smith, F.J.D., Milstone, L.M., Lane, E.B., Bale, S.J., Roop, D.R., McLean, W.H.I., and Kaspar, R.L. 2008. Therapeutic siRNAs for dominant genetic skin disorders including pachyonychia congenita. J. Dermatol. Sci. 51: 151-157.

Lechanteur, A., Sanna, V., Duchemin, A., Evrard, B., Mottet, D., and Piel, G. 2018. Cationic Liposomes Carrying siRNA: Impact of Lipid Composition on Physicochemical Properties, Cytotoxicity and Endosomal Escape. Nanomaterials 8 (5): 270, doi: 10.3390/nano8050270.

Lee, J., Yun, K.S., Choi, C.S., Shin, S.H., Ban, H.S., Rhim, T., Lee, S.K., and Lee, K.Y. 2012. T cell-specific siRNA delivery using antibody-conjugated chitosan nanoparticles. Bioconjug. Chem. 23: 1174-1180.

Lee, J., Saw, P.E., Gujrati, V., Lee, Y., Kim, H., Kang, S., Choi, M., Kim, J. I, and Jon, S. 2016. Mono-arginine cholesterol-based small lipid nanoparticles as a systemic sirna delivery platform for effective cancer therapy. Theranostics 6: 192-203.

Lee, J., and Ahn, H.J. 2018. PEGylated DC-Chol/DOPE cationic liposomes containing KSP siRNA as a systemic siRNA delivery Carrier for ovarian cancer therapy. Biochem. Biophys. Res. Commun. 503: 1716-1722.

Lee, J.B., Hong, J., Bonner, D.K., Poon, Z., and Hammond, P.T. 2012. Self-assembled RNA interference microsponges for efficient siRNA delivery. Nat. Mater. 11: 316-322.

Lee, S.H., Kang, Y.Y., Jang, H.E., and Mok, H. 2016. Current preclinical small interfering RNA (siRNA)-based conjugate systems for RNA therapeutics. Adv. Drug Deliv. Rev. 104: 78-92.

Lee, S.J., Yhee, J.Y., Kim, S.H., Kwon, I.C., and Kim, K. 2013. Biocompatible gelatin nanoparticles for tumor-targeted delivery of polymerized siRNA in tumor-bearing mice. J. Control. Release 172: 358-366.
Lee, S.J., Kim, M.J., Kwon, I.C., and Roberts, T.M. 2016. Delivery strategies and potential targets for siRNA in major cancer types. Adv. Drug Deliv. Rev. 104: 2-15.

Li, J., Chen, Y.C., Tseng, Y.C., Mozumdar, S., and Huang, L. 2010. Biodegradable calcium phosphate nanoparticle with lipid coating for systemic siRNA delivery. J. Control. Release 142: 416-421.

Li, L., Hou, J., Liu, X., Guo, Y., Wu, Y., Zhang, L., and Yang, Z. 2014. Nucleolin-targeting liposomes guided by aptamer AS1411 for the delivery of siRNA for the treatment of malignant melanomas. Biomaterials 35: 3840-3850.

Li, X., Zhao, Q., and Qiu, L. 2013. Smart ligand: Aptamermediated targeted delivery of chemotherapeutic drugs and siRNA for cancer therapy. J. Control. Release 171: 152-162.

Li, Y., Zhang, J., Wang, B., Shen, Y., and Ouahab, A. 2016. Codelivery of siRNA and hypericin into cancer cells by hyaluronic acid modified PLGA-PEI nanoparticles. Drug Dev. Ind. Pharm. 42: 737-746.

Liebow, A., Li, X., Racie, T., Hettinger, J., Bettencourt, B.R., Najafian, N., Haslett, P., Fitzgerald, K., Holmes, R.P., Erbe, D., et al. 2017. An Investigational RNAi Therapeutic Targeting Glycolate Oxidase Reduces Oxalate Production in Models of Primary Hyperoxaluria. J. Am. Soc. Nephrol. 28: 494-503.

Lin, Q., Chen, J., Zhang, Z., and Zheng, G. 2014. Lipid-based nanoparticles in the systemic delivery of siRNA. Nanomedicine 9: $105-120$.

Lin, X., Ruan, X., Anderson, M.G., McDowell, J.A., Kroeger, P.E., Fesik, S.W., and Shen, Y. 2005. siRNA-mediated off-target gene silencing triggered by a $7 \mathrm{nt}$ complementation. Nucleic Acids Res. 33: 4527-4535.

Liu, C., Liu, X., Rocchi, P., Qu, F., Iovanna, J.L., and Peng, L. 2014. Arginine-terminated generation 4 PAMAM dendrimer as an effective nanovector for functional siRNA delivery in vitro and in vivo. Bioconjug. Chem. 25: 521-532.

Liu, J., Gu, C., Cabigas, E.B., Pendergrass, K.D., Brown, M.E., Luo, Y., and Davis, M.E. 2013. Functionalized dendrimer-based delivery of angiotensin type 1 receptor siRNA for preserving cardiac function following infarction. Biomaterials 34: 3729-3736.

Liu, X., Liu, C., Laurini, E., Posocco, P., Pricl, S., Qu, F., Rocchi, P., and Peng, L. 2012. Efficient delivery of sticky siRNA and potent gene silencing in a prostate cancer model using a generation 5 triethanolamine-core PAMAM dendrimer. Mol. Pharm. 9: 470-481.

Liu, X., Wang, W., Samarsky, D., Liu, L., Xu, Q., Zhang, W., Zhu, G., Wu, P., Zuo, X., Deng, H., et al. 2014. Tumor-targeted in vivo gene silencing via systemic delivery of cRGD-conjugated siRNA. Nucleic Acids Res. 42: 11805-11817.

Liu, X., and Peng, L. 2016. Dendrimer nanovectors for siRNA delivery In: Methods in Molecular Biology. pp. 127-142. 
Please cite this article as

Chandela and Ueno, Reviews in Agricultural Science, 7:10-28, 2019

https://dx.doi.org/10.7831/ras.7.10

Liu, X.Q., Sun, C.Y., Yang, X.Z., and Wang, J. 2013. Polymericmicelle-based nanomedicine for siRNA delivery. Part. Part. Syst. Charact. 30: 211-228.

Lu, H., Wang, D., Kazane, S., Javahishvili, T., Tian, F., Song, F., Sellers, A., Barnett, B., and Schultz, P.G. 2013. Site-specific antibody-polymer conjugates for siRNA delivery. J. Am. Chem. Soc. 135: 13885-13891.

Ly, S., Navaroli, D.M., Didiot, M.C., Cardia, J., Pandarinathan, L., Alterman, J.F., Fogarty, K., Standley, C., Lifshitz, L.M., Bellve, K.D., et al. 2017. Visualization of self-delivering hydrophobically modified siRNA cellular internalization. Nucleic Acids Res. 45: 15-25.

Ma, D. 2014. Enhancing endosomal escape for nanoparticle mediated siRNA delivery. Nanoscale 6: 6415-6424.

Ma, Y., Kowolik, C.M., Swiderski, P.M., Kortylewski, M., Yu, H., Horne, D.A., Jove, R., Caballero, O.L., Simpson, A.J.G., Lee, F.T., et al. 2011. Humanized Lewis-Y specific antibody based delivery of STAT3 siRNA. ACS Chem. Biol. 6: 962-970.

Makita, Y., Murata, S., Katou, Y., Kikuchi, K., Uejima, H., Teratani, M., Hoashi, Y., Kenjo, E., Matsumoto, S., Nogami, M., et al. 2017. Anti-tumor activity of KNTC2 siRNA in orthotopic tumor model mice of hepatocellular carcinoma. Biochem. Biophys. Res. Commun. 493: 800-806.

Mamta, Reddy, K.R.K., and Rajam, M. V. 2016. Targeting chitinase gene of Helicoverpa armigera by host-induced RNA interference confers insect resistance in tobacco and tomato. Plant Mol. Biol. 90: 281-292.

Martínez, T., González, M.V., Roehl, I., Wright, N., Pañeda, C., and Jiménez, A.I. 2014. In vitro and in vivo efficacy of SYL040012, a novel siRNA compound for treatment of glaucoma. Mol. Ther. 22: 81-91.

Martirosyan, A., Olesen, M.J., and Howard, K.A. 2014. Chitosan-Based Nanoparticles for Mucosal Delivery of RNAi Therapeutics. Adv. Genet. 88: 325-352.

McNamara, J.O., Andrechek, E.R., Wang, Y., Viles, K.D., Rempel, R.E., Gilboa, E., Sullenger, B.A., and Giangrande, P.H. 2006. Cell type-specific delivery of siRNAs with aptamer-siRNA chimeras. Nat. Biotechnol. 24: 1005-1015.

Meade, B.R., and Dowdy, S.F. 2007. Exogenous siRNA delivery using peptide transduction domains/cell penetrating peptides. Adv. Drug Deliv. Rev. 59: 134-140.

Ming, X., and Laing, B. 2015. Bioconjugates for targeted delivery of therapeutic oligonucleotides. Adv. Drug Deliv. Rev. 87: 81-89.

Miteva, M., Kirkbride, K.C., Kilchrist, K. V., Werfel, T.A., Li, H., Nelson, C.E., Gupta, M.K., Giorgio, T.D., and Duvall, C.L. 2015. Tuning PEGylation of mixed micelles to overcome intracellular and systemic siRNA delivery barriers. Biomaterials 38: $97-107$.
Molitoris, B.A., Dagher, P.C., Sandoval, R.M., Campos, S.B., Ashush, H., Fridman, E., Brafman, A., Faerman, A., Atkinson, S.J., Thompson, J.D., et al. 2009. siRNA Targeted to p53 Attenuates Ischemic and Cisplatin-Induced Acute Kidney Injury. J. Am. Soc. Nephrol. 20: 1754-1764.

Moreno-Montañés, J., Bleau, A.M., and Jimenez, A.I. 2018. Tivanisiran, a novel siRNA for the treatment of dry eye disease. Expert Opin. Investig. Drugs 27: 421-426.

Nair, J.K., Willoughby, J.L.S., Chan, A., Charisse, K., Alam, M.R., Wang, Q., Hoekstra, M., Kandasamy, P., Kelin, A. V., Milstein, S., et al. 2014. Multivalent N -acetylgalactosamine-conjugated siRNA localizes in hepatocytes and elicits robust RNAimediated gene silencing. J. Am. Chem. Soc. 136: 1695-16961.

Ngamcherdtrakul, W., Morry, J., Gu, S., Castro, D.J., Goodyear, S.M., Sangvanich, T., Reda, M.M., Lee, R., Mihelic, S.A., Beckman, B.L., et al. 2015. Cationic Polymer Modified Mesoporous Silica Nanoparticles for Targeted SiRNA Delivery to HER2+ Breast Cancer. Adv. Funct. Mater. 25: 2646-2659.

Nguyen, Q.D., Schachar, R.A., Nduaka, C.I., Sperling, M., Basile, A.S., Klamerus, K.J., Chi-Burris, K., Yan, E., Paggiarino, D.A., Rosenblatt, I., et al. 2012. Phase 1 dose-escalation study of a siRNA targeting the RTP801 gene in age-related macular degeneration patients. Eye 26: 1099-1105.

Nimesh, S. 2012. Polyethylenimine as a Promising Vector for Targeted siRNA Delivery. Curr. Clin. Pharmacol. 7: 121-130.

Nourbakhsh, M., Behravan, J., Lage, H., Abnous, K., Mosaffa, F., Badiee, A., and Jaafari, M.R. 2015. Nanolipoparticles-mediated MDR1 siRNA delivery: preparation, characterization and cellular uptake. Nanomed J J.B. M.R.J 2: 39-45.

Nussbaumer, M.G., Duskey, J.T., Rother, M., Renggli, K., Chami, M., and Bruns, N. 2016. Chaperonin-Dendrimer Conjugates for siRNA Delivery. Adv. Sci. 3 (10): 1600046, doi: 10.1002/ advs.201600046.

Ogata, A., Maeda, Y., and Ueno, Y. 2017. Synthesis of antisense oligonucleotides containing acyclic alkynyl nucleoside analogs and their biophysical and biological properties. Bioorganic Med. Chem. 25: 2035-2042.

Ozcan, G., Ozpolat, B., Coleman, R.L., Sood, A.K., and LopezBerestein, G. 2015. Preclinical and clinical development of siRNA-based therapeutics. Adv. Drug Deliv. Rev. 87: 108-119.

Palanca-Wessels, M.C., Booth, G.C., Convertine, A.J., Lundy, B.B., Berguig, G.Y., Press, M.F., Stayton, P.S., and Press, O.W. 2016. Antibody targeting facilitates effective intratumoral siRNA nanoparticle delivery to HER2-overexpressing cancer cells. Oncotarget 7: 9561-9575.

Pan, M., Ni, J., He, H., Gao, S., and Duan, X. 2015. New paradigms on siRNA local application. BMB Rep. 48: 147-152.

Patil, Y., and Panyam, J. 2009. Polymeric nanoparticles for siRNA 
delivery and gene silencing. Int. J. Pharm. 367: 195-203.

Peng, S.F., Hsu, H.K., Lin, C.C., Cheng, Y.M., and Hsu, K.H. 2017. Novel PEI/Poly- $\gamma$-gutamic acid nanoparticles for high efficient siRNA and plasmid DNA co-delivery. Molecules 22 (1): 86, doi: 10.3390/molecules22010086.

Ragelle, H., Vandermeulen, G., and Préat, V. 2013. Chitosan-based siRNA delivery systems. J. Control. Release 172: 207-218.

Rajeev, K.G., Nair, J.K., Jayaraman, M., Charisse, K., Taneja, N., O’Shea, J., Willoughby, J.L.S., Yucius, K., Nguyen, T., Shulga-Morskaya, S., et al. 2015. Hepatocyte-Specific Delivery of siRNAs Conjugated to Novel Non-nucleosidic Trivalent N-Acetylgalactosamine Elicits Robust Gene Silencing in Vivo. ChemBioChem 16: 903-908.

Rizk, M., and Tüzmen, Ş. 2017. Update on the clinical utility of an RNA interference-based treatment: Focus on Patisiran. Pharmgenomics. Pers. Med. 10: 267-278.

Roberts, T.C., Ezzat, K., Andaloussi, S. El, and Weinberg, M.S. 2016. Synthetic SiRNA Delivery: Progress and Prospects. In: Shum K., Rossi J. (eds) SiRNA Delivery Methods. Methods in Molecular Biology, 1364: 291-310, Humana Press, New York, NY.

Sarett, S.M., Nelson, C.E., and Duvall, C.L. 2015. Technologies for controlled, local delivery of siRNA. J. Control. Release $\mathbf{2 1 8}$ : 94-113.

Schirle, N.T., and MacRae, I.J. 2012. The crystal structure of human argonaute2. Science, 336: 1037-1040.

Schultheis, B., Strumberg, D., Kuhlmann, J., Wolf, M., Link, K., Seufferlein, T., Kaufmann, J., Gebhardt, F., Bruyniks, N., and Pelzer, U. 2016. A phase Ib/IIa study of combination therapy with gemcitabine and Atu027 in patients with locally advanced or metastatic pancreatic adenocarcinoma. J. Clin. Oncol. 34:4_ suppl, 385-385, doi: 10.1200/jco.2016.34.4_suppl.385.

Sebestyén, M.G., Wong, S.C., Trubetskoy, V., Lewis, D.L., and Wooddell, C.I. 2015. Targeted In Vivo Delivery of siRNA and an Endosome-Releasing Agent to Hepatocytes. Methods Mol. Biol. 1218: 163-86.

Sharp, P.A. 2001. RNA interference - 2001. Genes Dev. 15: 485-490.

Shrestha, R., Elsabahy, M., Florez-Malaver, S., Samarajeewa, S., and Wooley, K.L. 2012. Endosomal escape and siRNA delivery with cationic shell crosslinked knedel-like nanoparticles with tunable buffering capacities. Biomaterials 33: 8557-8568.

Shukla, S., Sumaria, C.S., and Pradeepkumar, P.I. 2010. Exploring chemical modifications for siRNA therapeutics: A structural and functional outlook. ChemMedChem 5: 328-349.

Sierant, M., Yang, X., and Nawrot, B. 2013. Sirna analogs containing phosphorodithioate substitutions In: Phosphorus, Sulfur and Silicon and the Related Elements. pp. 427-436.

Sivakumar, P., Kim, S., Kang, H.C., and Shim, M.S. 2018. Targeted siRNA delivery using aptamer-siRNA chimeras and aptamer-conjugated nanoparticles. Wiley Interdiscip. Rev. Nanomedicine Nanobiotechnology e1543, doi: 10.1002/ wnan. 1543 .

Song, J., Zhang, Y., Zhang, W., Chen, J., Yang, X., Ma, P., Zhang, B., Liu, B., Ni, J., and Wang, R. 2015. Cell penetrating peptide TAT can kill cancer cells via membrane disruption after attachment of camptothecin. Peptides 63: 143-149.

Srimanee, A., Arvanitidou, M., Kim, K., Hällbrink, M., and Langel, Ü. 2018. Cell-penetrating peptides for siRNA delivery to glioblastomas. Peptides 104: 62-69.

Strumberg, D., Schultheis, B., Traugott, U., Vank, C., Santel, A., Keil, O., Giese, K., Kaufmann, J., and Drevs, J. 2011. First-inhuman phase I study of Atu027, a liposomal small interfering RNA formulation, targeting protein kinase N3 (PKN3) in patients with advanced solid tumors. J. Clin. Oncol. 29: 15 suppl 3057-3057, doi: 10.1200/jco.2011.29.15_suppl.3057.

Suter, S.R., Sheu-Gruttadauria, J., Schirle, N.T., Valenzuela, R., Ball-Jones, A.A., Onizuka, K., Macrae, I.J., and Beal, P.A. 2016. Structure-Guided Control of siRNA Off-Target Effects. $J$. Am. Chem. Soc. 138: 8667-8669.

Takemoto, H., and Nishiyama, N. 2017. Functional polymer-based siRNA delivery carrier that recognizes site-specific biosignals. $J$. Control. Release 267: 90-99.

Tanaka, K., Kanazawa, T., Horiuchi, S., Ando, T., Sugawara, K., Takashima, Y., Seta, Y., and Okada, H. 2013. Cytoplasmresponsive nanocarriers conjugated with a functional cellpenetrating peptide for systemic siRNA delivery. Int. J. Pharm. 455: 40-47.

Tang, Y., Li, Y.B., Wang, B., Lin, R.Y., Dongen, M. Van, Zurcher, D.M., Gu, X.Y., Banaszak Holl, M.M., Liu, G., and Qi, R. 2012. Efficient in vitro siRNA delivery and intramuscular gene silencing using PEG-modified PAMAM dendrimers. Mol. Pharm. 9: 1812-1821.

Taratula, O., Garbuzenko, O.B., Kirkpatrick, P., Pandya, I., Savla, R., Pozharov, V.P., He, H., and Minko, T. 2009. Surfaceengineered targeted PPI dendrimer for efficient intracellular and intratumoral siRNA delivery. J. Control. Release 140: 284-293.

Tezgel, Ö., Szarpak-Jankowska, A., Arnould, A., Auzély-Velty, R., and Texier, I. 2018. Chitosan-lipid nanoparticles (CS-LNPs): Application to siRNA delivery. J. Colloid Interface Sci. 510: 45-56.

Thiel, K.W., Hernandez, L.I., Dassie, J.P., Thiel, W.H., Liu, X., Stockdale, K.R., Rothman, A.M., Hernandez, F.J., McNamara, J.O., and Giangrande, P.H. 2012. Delivery of chemo-sensitizing siRNAs to HER2+-breast cancer cells using RNA aptamers. Nucleic Acids Res. 40: 6319-6337.

Tietze, S., Schau, I., Michen, S., Ennen, F., Janke, A., Schackert, G., Aigner, A., Appelhans, D., and Temme, A. 2017. A Poly(Propyleneimine) Dendrimer-Based Polyplex-System 
Please cite this article as

Chandela and Ueno, Reviews in Agricultural Science, 7:10-28, 2019

https://dx.doi.org/10.7831/ras.7.10

for Single-Chain Antibody-Mediated Targeted Delivery and Cellular Uptake of SiRNA. Small 13: 1700072, doi: 10.1002/ smll.201700072.

Tuschl, T. 2001. RNA interference and small interfering RNAs. ChemBioChem 2: 239-245.

Tushir-Singh, J. 2017. Antibody-siRNA conjugates: drugging the undruggable for anti-leukemic therapy. Expert Opin. Biol. Ther. 17: 325-338.

Tuttolomondo, M., Casella, C., Hansen, P.L., Polo, E., Herda, L.M., Dawson, K.A., Ditzel, H.J., and Mollenhauer, J. 2017. Human DMBT1-Derived Cell-Penetrating Peptides for Intracellular siRNA Delivery. Mol. Ther. - Nucleic Acids 8: 264-276.

Ueno, Y., Inoue, T., Yoshida, M., Yoshikawa, K., Shibata, A., Kitamura, Y., and Kitade, Y. 2008. Synthesis of nucleaseresistant siRNAs possessing benzene-phosphate backbones in their 3'-overhang regions. Bioorganic Med. Chem. Lett. 18: 5194-5196.

Ueno, Y., Watanabe, Y., Shibata, A., Yoshikawa, K., Takano, T., Kohara, M., and Kitade, Y. 2009. Synthesis of nuclease-resistant siRNAs possessing universal overhangs. Bioorganic Med. Chem. 17: 1974-1981.

Urbiola, K., Blanco-Fernández, L., Ogris, M., Rödl, W., Wagner, E., and Ilarduya, C.T. de 2018. Novel PAMAM-PEG-peptide conjugates for siRNA delivery targeted to the transferrin and epidermal growth factor receptors. J. Pers. Med. 8 (1): 4, doi: 10.3390/jpm8010004.

Valencia-Serna, J., Landry, B., Jiang, X., and Uludag, H. 2014. Potential of siRNA Therapy in Chronic Myeloid Leukemia. In: Prokop A., Iwasaki Y., Harada A. (eds) Intracellular Delivery II. Fundamental Biomedical Technologies, 7: 435-473, Springer, Dordrecht.

Valenzuela, R.A.P., Suter, S.R., Ball-Jones, A.A., Ibarra-Soza, J.M., Zheng, Y., and Beal, P.A. 2014. Base modification strategies to modulate immune stimulation by an siRNA. ChemBioChem 16: 262-267.

Wagner, E. 2012. Polymers for siRNA delivery: Inspired by viruses to be targeted, dynamic, and precise. Acc. Chem. Res. 45: 1005-1013.

Wang, J., Ayano, E., Maitani, Y., and Kanazawa, H. 2017. Enhanced cellular uptake and gene silencing activity of siRNA using temperature-responsive polymer-modified liposome. Int. J. Pharm. 523: 217-228.

Wang, J., Lu, Z., Wientjes, M.G., and Au, J.L.-S. 2010. Delivery of siRNA Therapeutics: Barriers and Carriers. AAPS J. 12: 492-503.

Whitehead, K.A., Dahlman, J.E., Langer, R.S., and Anderson, D.G. 2011. Silencing or Stimulation? siRNA Delivery and the Immune System. Annu. Rev. Chem. Biomol. Eng. 2: 77-96.

Whitehead, K.A., Langer, R., and Anderson, D.G. 2009. Knocking down barriers: Advances in siRNA delivery. Nat. Rev. Drug Discov. 8: 129-138.

Willoughby, J.L.S., Chan, A., Sehgal, A., Butler, J.S., Nair, J.K., Racie, T., Shulga-Morskaya, S., Nguyen, T., Qian, K., Yucius, K., et al. 2018. Evaluation of GalNAc-siRNA Conjugate Activity in Pre-clinical Animal Models with Reduced Asialoglycoprotein Receptor Expression. Mol. Ther. 26: 105-114.

Wu, J., Huang, W., and He, Z. 2013. Dendrimers as Carriers for siRNA Delivery and Gene Silencing : A Review. 2013: 630654, doi: $10.1155 / 2013 / 630654$.

Wu, S.Y., Lopez-Berestein, G., Calin, G.A., and Sood, A.K. 2014. RNAi therapies: Drugging the undruggable. Sci. Transl. Med. 6 (240): 240ps7.

Xia, W., and Lin, C. 2012. Bioreducible polymer-delivered siRNA targeting human telomerase reverse transcriptase for human cancer gene therapy. Ther. Deliv. 3: 439-442.

Xiong, X.B., Uludaĝ, H., and Lavasanifar, A. 2010. Virus-mimetic polymeric micelles for targeted siRNA delivery. Biomaterials 31: 5886-5893.

Xu, L., Wang, X., He, H., Zhou, J., Li, X., Ma, H., Li, Z., Zeng, Y., Shao, R., Cen, S., et al. 2015. Structure-based design of novel chemical modification of the $3^{\prime}$-overhang for optimization of short interfering RNA performance. Biochemistry 54: 1268-1277.

Xue, H.Y., Liu, S., and Wong, H.L. 2014. Nanotoxicity: A key obstacle to clinical translation of sirna-based nanomedicine. Nanomedicine 9: 295-312.

Yang, Y., Li, J., Liu, F., and Huang, L. 2012. Systemic delivery of siRNA via LCP nanoparticle efficiently inhibits lung metastasis. Mol. Ther. 20: 609-615.

Yang, Y., Yang, Y.F., Xie, X.Y., Wang, Z.Y., Gong, W., Zhang, H., Li, Y., Yu, F.L., Li, Z.P., and Mei, X.G. 2015. Dual-modified liposomes with a two-photon-sensitive cell penetrating peptide and NGR ligand for siRNA targeting delivery. Biomaterials 48: 84-96.

Youn, P., Chen, Y., and Furgeson, D.Y. 2014. A myristoylated cellpenetrating peptide bearing a transferrin receptor-targeting sequence for neuro-targeted siRNA delivery. Mol. Pharm. 11: 486-495.

Younis, A., Siddique, M.I., Kim, C.K., and Lim, K.B. 2014. RNA interference (RNAi) induced gene silencing: A promising approach of hi-tech plant breeding. Int. J. Biol. Sci. 10: 1150-1158.

Zheng, M., Tao, W., Zou, Y., Farokhzad, O.C., and Shi, B. 2018. Nanotechnology-Based Strategies for siRNA Brain Delivery for Disease Therapy. Trends Biotechnol. 36: 562-575.

Zhou, J., Li, H., Li, S., Zaia, J., and Rossi, J.J. 2008. Novel dual inhibitory function aptamer-siRNA delivery system for HIV-1 therapy. Mol. Ther. 16: 1481-1489.

Zhou, J., Li, H., Zhang, J., Piotr, S., and Rossi, J. 2011. Development of Cell-type specific anti-HIV gp120 aptamers for 
siRNA delivery. J. Vis. Exp. (52), 2954. doi:10.3791/2954.

Zhou, J., Patel, T.R., Fu, M., Bertram, J.P., and Saltzman, W.M. 2012. Octa-functional PLGA nanoparticles for targeted and efficient siRNA delivery to tumors. Biomaterials 33: 583-591.

Zhou, Z., Liu, S., Zhang, Y., Yang, X., Ma, Y., Guan, Z., Wu, Y., Zhang, L., and Yang, Z. 2017. Reductive nanocomplex encapsulation of cRGD-siRNA conjugates for enhanced targeting to cancer cells. Int. J. Nanomedicine 12: 7255-7272.

Zimmermann, T.S., Karsten, V., Chan, A., Chiesa, J., Boyce, M., Bettencourt, B.R., Hutabarat, R., Nochur, S., Vaishnaw, A., and Gollob, J. 2017. Clinical Proof of Concept for a Novel HepatocyteTargeting GalNAc-siRNA Conjugate. Mol. Ther. 25: 71-78.

Zimmermann, T.S., Karsten, V., Harrop, J., Chan, A., Chiesa, J., Peters, G., Falzone, R., Cehelsky, J., Nochur, S., Vaishnaw, A., Gollob, J., 2013. Phase I first-in-humans trial of ALN-TTRSC, a novel RNA interference therapeutic for the treatment of familial amyloidotic cardiomyopathy (FAC). J. Card. Fail. 19: S66, doi: 10.1016/j.cardfail.2013.06.214.

Zuckerman, J.E., Choi, C.H.J., Han, H., and Davis, M.E. 2012. Polycation-siRNA nanoparticles can disassemble at the kidney glomerular basement membrane. Proc. Natl. Acad. Sci. 109: 3137-3142.

Zuckerman, J.E., and Davis, M.E. 2015. Clinical experiences with systemically administered siRNA-based therapeutics in cancer. Nat. Rev. Drug Discov. 14: 843-856.

Zuckerman, J.E., Gritli, I., Tolcher, A., Heidel, J.D., Lim, D., Morgan, R., Chmielowski, B., Ribas, A., Davis, M.E., and Yen, Y. 2014. Correlating animal and human phase Ia/Ib clinical data with CALAA-01, a targeted, polymer-based nanoparticle containing siRNA. Proc. Natl. Acad. Sci. 111: 11449-11454. 